IZA DP No. 6766

An Anatomy of Racial and Ethnic Trends in Male Earnings

John V. Winters

Barry T. Hirsch

July 2012 


\title{
An Anatomy of Racial and Ethnic Trends in Male Earnings
}

\author{
John V. Winters \\ University of Cincinnati \\ and IZA
}

Barry T. Hirsch

Georgia State University

and IZA

\section{Discussion Paper No. 6766 \\ July 2012}

IZA
P.O. Box 7240
53072 Bonn
Germany

Phone: +49-228-3894-0

Fax: +49-228-3894-180

E-mail: iza@iza.org

\begin{abstract}
Any opinions expressed here are those of the author(s) and not those of IZA. Research published in this series may include views on policy, but the institute itself takes no institutional policy positions.

The Institute for the Study of Labor (IZA) in Bonn is a local and virtual international research center and a place of communication between science, politics and business. IZA is an independent nonprofit organization supported by Deutsche Post Foundation. The center is associated with the University of Bonn and offers a stimulating research environment through its international network, workshops and conferences, data service, project support, research visits and doctoral program. IZA engages in (i) original and internationally competitive research in all fields of labor economics, (ii) development of policy concepts, and (iii) dissemination of research results and concepts to the interested public.
\end{abstract}

IZA Discussion Papers often represent preliminary work and are circulated to encourage discussion. Citation of such a paper should account for its provisional character. A revised version may be available directly from the author. 


\section{ABSTRACT}

\section{An Anatomy of Racial and Ethnic Trends in Male Earnings ${ }^{*}$}

Progress in narrowing black-white earnings differences has been far from continuous, with some of the apparent progress resulting from labor force withdrawal among lower-skilled African Americans. This paper builds on prior research and documents racial and ethnic differences in male earnings from 1950 through 2010 using data from the decennial census and American Community Surveys. Emphasis is given to annual rather than weekly or hourly earnings. Treatment of imputed earnings greatly affects measured outcomes. We take a quantile approach, providing evidence on medians and other percentiles of the distribution. Black male joblessness rose to over $40 \%$ in 2010 , the median black-white earnings gap being the largest in at least sixty years. The experience of black men contrasts with that of Hispanic men during the last decade, who exhibited earnings growth similar to white men. Black men are being left behind economically, a process exacerbated by weak labor market conditions.

JEL Classification: J15, J31

Keywords: inequality, race, earnings, wages, median regression, imputed earnings

Corresponding author:

Barry T. Hirsch

Department of Economics

Andrew Young School of Policy Studies

Georgia State University

Atlanta, GA 30302-3992

USA

E-mail: bhirsch@gsu.edu

\footnotetext{
* We thank Peter McHenry, Derek Neal, Dennis Sullivan, and seminar participants for helpful comments on the paper.
} 


\section{Introduction}

Racial differences in income and employment outcomes have been of considerable interest to researchers, policymakers, and laypersons for some time. ${ }^{1}$ Earnings differentials between blacks and whites in the U.S. have received particular attention, with researchers having documented that the black-white earnings gap in the U.S. decreased considerably after 1940 (Smith and Welch 1989; Margo 1995; Chandra 2000; Couch and Daly 2002; Black et al. 2009). ${ }^{2}$ Black-white relative earnings, however, have not increased without interruption. Bound and Freeman (1992) suggest that relative earnings for young black men decreased from the mid1970s through the 1980s. Subsequent work has focused on deterioration in relative black-white earnings concentrated among those with little education (Neal 2006). ${ }^{3}$

Researchers following Butler and Heckman (1977) and Brown (1984) have noted the increasing frequency of labor market dropout by black men, especially those with low skills. In fact, much of the observed convergence in black-white relative earnings results from the selective withdrawal of low-skilled blacks from the labor market (Butler and Heckman 1977; Brown 1984; Chandra 2003; Juhn 2003; Antecol and Bedard 2004). ${ }^{4}$ Labor market dropouts would have had relatively low earnings were they employed, so their withdrawal causes

\footnotetext{
${ }^{1}$ Altonji and Blank (1999) review the literature on race and gender in the labor market. Kim (2009) examines gender differences in the earnings of black workers.

2 The terms "black" and "white" in this paper are used to refer to non-Hispanic blacks and non-Hispanic whites. We define "Hispanics" as Hispanics of any race.

${ }^{3}$ Mok and Siddique (2011) examine racial and ethnic differences in employer provided fringe benefits using the NLSY79 and NLSY97. They find that in both surveys, African-Americans had lower levels of fringe benefits than comparable whites and Hispanics.

${ }^{4}$ Western and Pettit (2005), Raphael (2006), and Pettit (2012) argue that much of the increase in black male joblessness after 1980 can be attributed to increased incarceration in jails and prisons. Raphael and Stoll (2009) suggest that the increased incarceration rates were due mostly to changes in sentencing policy. Holzer et al. (2005) argue that the declining employment of young black less-educated men is largely attributable to prior incarceration and increased enforcement of child support payments. Borjas et al. (2010) show that increased immigration has played an important role in both the decrease in employment and increase in incarceration for black men. Several researchers suggest that "spatial mismatch" between inner city blacks and suburban jobs exacerbates black employment woes (Holzer 1991; Ihlanfeldt and Sjqouist 1998; Brueckner and Zenou 2003). Finally, some researchers argue that racial discrimination is an important factor (Ritter and Taylor 2011; Lang and Lehmann 2011; Fryer et al. 2011).
} 
observed black earnings to be overstated and the black-white earnings gap to be understated.

Because black non-employment has increased, researchers who do not account for selection over time will overstate the extent to which black-white earnings have converged.

This paper builds on previous research by documenting racial and ethnic differences in male earnings and their trends over time. Though the paper does not explicitly analyze the underlying or fundamental causes of these differences, providing descriptive evidence on the magnitudes, time trends, and proximate correlates of earnings differentials is highly informative. We give special attention to the years from 2000 to 2010, a time period that includes the Great Recession and over which racial differences in earnings have received limited attention. Though our primary focus is on racial differences in earnings, we examine similar evidence for Hispanics, who are often excluded or ignored in studies that focus on race. ${ }^{5}$ We differ from most previous studies in our focus on annual rather than weekly or hourly earnings. An important difference between our paper and most of the literature is that rather than focusing on mean differences in earnings, our paper takes a quantile approach, focusing on differences at the median and other percentiles of the earnings distribution.

In what follows, we find that black male joblessness not only continued its long-run increase, but increased sharply during the first decade of the $21^{\text {st }}$ century. In 2010 , the median log earnings gap between white and black men was the largest such gap since at least 1950 . Much of the increased joblessness and divergence in earnings is due to the recession and slow

\footnotetext{
${ }^{5}$ A recent paper by Hoynes et al. (2012) provides a careful analysis of who is hurt during recessions based on crossstate differences in the business cycle during the early 1980s and the 2007 recession. Although their focus and methods are very different from our paper, their broad conclusions align with those reported here. They conclude that black, Hispanic, male, young, and less educated workers are most harmed in a recession. As we report in our paper, they find employment changes during the Great Recession to be similar for Hispanic and white men (in sharp contrast to the early 1980s), while employment losses among black men are substantially larger.
} 
economic recovery. ${ }^{6}$ Yet well before the recession that began officially in December 2007, the black-white earnings gap had already started to grow. The first decade of the new millennium has been a difficult one for the employment prospects of black men, especially those poorly educated and at the low end of the wage distribution. ${ }^{7}$ The experience of Hispanic men stands in sharp contrast to the recent experience of black men. Between 2000 and 2010, Hispanic nonemployment was relatively stable, as was the Hispanic-white earnings gap.

The remainder of the paper proceeds as follows. The next section discusses the data sources used and the important issue of imputed earners. A third section documents overall trends in male earnings between 1950 and 2010, while a fourth section uses quantile regression to estimate black-white and Hispanic-white log earnings gaps, controlling for individual age, education, and location. A fifth section addresses concerns regarding heaped earnings data.

\section{Data}

This paper uses microdata from the 1950-2000 decennial censuses and the 2006-2010 American Community Surveys (ACS), all available from the Integrated Public Use Microdata Series (IPUMS) produced and distributed by Ruggles et al. (2010). Each sample used is a nationally representative one percent sample of the U.S. male population and includes nonearners and the institutionalized population. ${ }^{8}$ We treat non-earners as having zero earnings, rather than trying to impute their hypothetical potential earnings. That is, we measure racial and ethnic differences in realized earnings, conditional on measured attributes, and not what workers

\footnotetext{
${ }^{6}$ Black well-being is typically more sensitive to labor market cyclicality than is that for whites (Ewing et al. 2002; McLennan 2003; and Hoynes et al. 2012).

${ }^{7}$ High and increasing rates of joblessness among those least educated, as documented subsequently, is consistent with recent studies showing that incomes among households (defined comprehensively) in the lower portions of the distribution are increasingly dependent on government transfers (e.g., Wolff et al. 2012).

${ }^{8}$ The ACS was also conducted annually from 2000-2005, but those surveys did not include the institutionalized population and are therefore not included in this study.
} 
might have earned. ${ }^{9}$ The institutionalized population consists primarily of persons in correctional institutions, especially after 1980, but also includes persons in institutions for the mentally ill, those with severe physical disabilities, and those otherwise homeless (the elderly are not included in our analysis). Chandra (2003), Pettit (2012), and Western and Pettit (2005) have shown the importance of including the institutionalized population to account for selection effects in studies on racial differences in employment and earnings.

We restrict the sample to native-born men who are white, black, or Hispanic between the ages of 18 and 61 at the time of the survey and not enrolled in school or college. We measure earnings primarily based on annual earnings during the previous year and include wage and salary, business, and farm incomes. For the decennial censuses, the reference period for earnings is the previous calendar year, e.g. earnings in the 2000 Census are for the 1999 calendar year. The ACS, however, is conducted throughout the year and the reference period for earnings is the previous 12 months prior to the survey. All dollar amounts are converted to 1999 values using the Consumer Price Index (CPI) produced by the Bureau of Labor Statistics (BLS).

Omitted from our principal analysis are individuals who did not report their earnings but for whom the Census Bureau imputes earnings using a hot deck procedure. Although item nonresponse is low for most survey questions, the exception is for measures of earnings and income. Inclusion of imputed values can seriously bias estimates of earnings, typically causing attenuation of measured earnings differentials. This attenuation (so-called "match bias") is particularly severe with respect to earnings attributes that are not match attributes or are matched imperfectly in the

\footnotetext{
${ }^{9}$ Of course, potential earnings are zero (or close to zero) for a substantial number of non-earners. Quantile regression is less sensitive than would be ordinary least squares regression to the inclusion of non-earners' potential earnings. For example, quantile estimates at the median would be identical with or without such imputations if all non-earners had potential earnings below the $50^{\text {th }}$ percentile. To the extent that non-workers have potential earnings greater than the $\mathrm{X}$ percentile, quantile regression will understate hypothetical earnings for non-workers and for groups with large numbers of non-workers. For most non-earners, predicted earnings would be biased upward were they based on measured characteristics and estimated parameters from an earners-only sample.
} 
hot deck procedure (Bollinger and Hirsch 2006). The quality of matches is likely to be particularly poor for African-Americans or other minority groups (Lillard et al. 1986). While the inclusion of imputed values, typical in most studies, can introduce substantial bias in estimated earnings differentials, their inclusion does nothing to correct for non-ignorable response bias because non-respondents are assigned earnings values from individuals who do respond (Bollinger and Hirsch, forthcoming). Omission of imputed earners can change the composition of the sample with respect to measurable variables (e.g., age, education, and location), but this can be readily accounted for by reweighting the respondent sample based on the inverse probability of response (Bollinger and Hirsch 2006; Wooldridge 2002, 587-588), an approach we follow in our analysis. We find that the gap between black and white earnings is substantially understated when imputed values are included, a result previously found by Neal (2006). ${ }^{10}$

Also important is either the omission or separate treatment for foreign-born men, whose labor force participation and earnings differ from the native born and whose inclusion noticeably affects the level and trend in Hispanic-white and, to a lesser extent, black-white wage gaps.

Most prior studies have examined racial differences in weekly or hourly earnings, but we follow Black et al. (2010) and focus primarily on annual earnings. Annual earnings reflect not only the price of labor services but also the number of weeks and hours worked during the year, thus providing a more complete picture of the economic disparities between groups. It is informative, however, to briefly compare racial/ethnic differences in median annual earnings, weekly earnings, wages, and annual hours worked, which we do using the 2000 Census. Weekly

\footnotetext{
${ }^{10}$ Neal (2006) does not reweight his samples to account for changes in composition due to non-response. Although exclusion of imputed values substantially increases estimates of racial earnings gaps, we find that results are relatively insensitive to reweighting the samples. Non-response rates for the 2006-2010 ACS are about 15-18 percent for whites, 26-28 percent for blacks, and 24-26 percent for Hispanics. Non-response rates from the 1980, 1990, and 2000 decennial Censuses are a good bit higher. Non-response rates were far lower in 1950 (about 10 percent for whites and Hispanics and 14 percent for blacks) than in 1980 through 2010. The 1960 decennial Census from IPUMS does not include imputation flags, while the reported rates for 1970 appear unrealistically low.
} 
earnings are computed by dividing annual earnings by the number of weeks worked the previous year; hourly wages are computed by dividing weekly earnings by the usual number of hours worked per week the previous year; and annual hours are the product of usual hours worked per week and the number of weeks worked the previous year. ${ }^{11}$ Persons with zero annual earnings are also defined to have zero weekly and hourly earnings.

Table 1 reports the median values for black, Hispanic, and white men and the logarithmic difference in medians between whites and blacks and whites and Hispanics. Median annual earnings for black and Hispanic men reported in 2000 were $\$ 17,000$ and $\$ 21,000$, respectively. ${ }^{12}$ The median annual earnings among whites was $\$ 33,000,0.66$ and 0.45 log points higher than for blacks and Hispanics (the log differences can be loosely interpreted as a percentage difference using an intermediate earnings base for the two groups). The log differences in annual earnings are much higher than for median weekly earnings (at 0.32 and 0.31$)$ and hourly earnings $(0.28$ and 0.27 ) due to fewer annual hours worked by black than by white and Hispanic men. Comparing annual earnings therefore paints not only a more complete but also a bleaker picture of economic disparities between white and black men. In the analysis that follows, we retain a focus on annual earnings differences.

\section{Earnings Trends, 1950-2010}

\subsection{Shares of Non-Earners}

We next examine trends in annual earnings from 1950-2010 among black, Hispanic, and white men. Figure 1 shows the trends in the share of men without positive annual earnings over

\footnotetext{
${ }^{11}$ Baum-Snow and Neal (2009) suggest that many persons appear to respond to the usual hours worked per week question in the Census survey as if they are reporting their usual hours worked per day and the frequency of this error differs by race and gender. If so, this will bias observed racial (and possibly ethnic) gaps in hourly earnings and annual hours worked, all the more reason to focus primarily on annual earnings.

${ }^{12}$ One sees in Table 1 the tendency for respondents to report rounded values for earnings. This tendency is masked when mean values are reported, but readily evident when medians are reported in current year dollars (the 2000 Census reports 1999 earnings). In a subsequent section we address the issue of heaped earnings at rounded values.
} 
this period; values are also reported in Appendix Table A. ${ }^{13}$ Since 1970 there has been a remarkable increase in the share of black men with no annual earnings. That share has gone from 15 percent in 1970 to 29 percent in 2000 and to nearly 42 percent by 2010 . That is, two out of every five black men ages 18-61 had no earned income in the previous year. Of course, the extraordinarily high current non-earnings rates are due in part to the economic recession that began in December 2007, but black male joblessness saw meaningful increases during the 1970s and the 1990s, and every decade since the 1960s has shown an increase. Long-term trends among white and Hispanic males also display long-run increases in the proportion of nonearners, but at levels far below those among black males. Joblessness among Hispanic males increased from roughly 10 to 17 percent between 1970 and 2000. It decreased between 2000 and 2008, but by 2010 the share of Hispanic non-earners had risen to 24 percent. The white male non-earners share increased continuously after 1970 and was 17 percent in 2010, moderately lower than the rate among Hispanics and well below that among African Americans.

On average, blacks and Hispanics have less education and are generally younger than whites. These differences may account for some differences in non-earnings since younger and less educated individuals tend to have weaker labor force attachment, all else the same, while school attendance can directly decrease labor force participation (students are omitted from our analysis). Figures $2 \mathrm{a}-\mathrm{f}$ looks at the trends and differences in the shares of non-earners between 2000 and 2010 in more detail by examining the non-earner rates for black, Hispanic, and white males by age and education group; values are also reported in Appendix Table B. We consider

\footnotetext{
${ }^{13}$ Robinson et al. (2002) use vital statistics to suggest that the Census undercounts some groups of the population, especially black men. If the uncounted men have worse employment outcomes than those counted, then actual nonemployment shares would be even higher than those observed. Similarly, Neal (2006) suggests that the Census data include allocated employment information for some non-responders that may not be fully credible. Counting as non-earners individuals with what Neal (2006) considers non-credible responses to the work questions would increase the non-earner share even further.
} 
eight age groups for men, ages 18-24, 25-29, 30-34, 35-39, 40-44, 45-49, 50-54, and 55-61. We also investigate four education groups: those with less than a high school diploma, those with a high school diploma but no college, those with some college but less than a four year degree, and those with a four year college degree or higher. For all race/ethnic groups, the share of nonearners decreases with the level of education. Age has a non-monotonic U-shape effect: the share of non-earners is lowest for those in the middle of the age distribution and highest for the youngest and oldest groups who have weaker labor force attachment as they transition from school to work and from work to retirement, respectively.

The numbers also suggest that the differences in 2000 and 2010 between blacks and whites in the share of men without earnings are not simply due to blacks being younger and less educated. Even within age and education groups, black males tend to have far higher non-earner rates than comparable whites and Hispanics. For example among those without a high school diploma, the share of black non-earners in 2000 was 0.57 , compared to 0.35 among Hispanics and 0.30 among whites. The situation in 2010 was far worse for black, Hispanic, and white high school dropouts, with non-earner shares of $0.72,0.45$, and 0.46 , respectively. Dropouts ages 18 24 had among the highest non-earnings rates in 2010, at 0.78 for black males, 0.50 for Hispanics, and 0.46 for whites. Having more than three-quarters of young black male dropouts report no annual earnings in the 2010 survey is particularly troubling. To the extent that early labor market experience influences subsequent outcomes, it would be surprising if this cohort does not continue to struggle. College graduates, on the other hand, have not done so poorly in the first decade of the twenty-first century. The non-earner share did increase between 2000 and 2010 for both black and white college graduates, from 0.08 to 0.12 and from 0.04 to 0.06 , respectively, but the levels remained far lower than for their counterparts with less education. 
In work not shown (but available on request), we explored whether or not measured covariates could account for the large differences by race and ethnicity in non-earnings. Using a linear probability model for non-earnings among individuals by year, we first regress nonearnings on race and ethnicity, which reproduces the information shown in Table 4, panel A. We then add age, then education, and then location. The results reinforce prior conclusions. For black men, age and location explain close to none of the large black-white difference in nonearnings, while education accounts for a meaningful but modest share (about 20\%). Among Hispanic men, age does not explain non-earnings differences, but education accounts for about half and location about 15 percent of the total Hispanic-white non-earnings difference. The "unexplained" ethnic difference in the non-earnings is small, about 2 to $2 \frac{1}{2}$ percentage points.

We also narrowed our primary sample down to those who had worked within the past five years, a sample for which industry and occupation is recorded not only for those with a current job, but also for those who worked previously. As expected, this restricted sample displays rates of current non-earnings far lower (roughly half) than for our full sample.

Controlling for industry and occupation in addition to age, education, and location, however, does little or nothing to further explain racial or ethnic differences in non-earnings.

\subsection{Real Annual Earnings: 1950-2010}

Figures 3a-d display real annual earnings (in 1999\$) between 1950 and 2010 for men at the $25^{\text {th }}, 50^{\text {th }}$ (median), $75^{\text {th }}$, and $90^{\text {th }}$ percentiles (values are reported in Appendix Table A). Percentiles are for a full sample of men that includes those who are institutionalized, plus other non-earners. Earnings at the $25^{\text {th }}$ percentile for black men increased between 1950 and 1970, but this measure is rather uninformative after 1970 because it is dominated by zero earners.

Earnings at the $25^{\text {th }}$ percentiles among Hispanics and whites also increased sharply between 1950 
and 1960, grew modestly during the 1960s, and then steadily declined over several decades. Earnings for this group stabilized in 2006-2008 before dropping steeply in 2009 and 2010. Between 2000 and 2007 earnings at the $25^{\text {th }}$ percentile for Hispanics increased, followed by decreases in 2008, 2009, and 2010. Earnings in the $25^{\text {th }}$ percentile for white males decreased from $\$ 17,000$ to $\$ 14,191$ between 2000 and 2008 , and then fell sharply to $\$ 7,856$ by 2010 .

Median real annual earnings increased substantially during the 1950s and the 1960s for all three racial/ethnic groups, but then were roughly flat in the 1970s, 1980s, and 1990s. Between 2000 and 2006 real median earnings for black males fell by 30 percent from $\$ 17,000$ to $\$ 12,593$. By 2010 real median annual earnings for blacks had fallen to $\$ 5,546$, below its value in 1950. Median earnings for Hispanic males changed little between 2000 and 2008, from $\$ 21,000$ to $\$ 20,498$, but by 2010 had decreased to $\$ 15,405$. For white males median earnings decreased from $\$ 33,000$ in 2000 to $\$ 27,498$ in $2010 .^{14}$

Earnings at the $75^{\text {th }}$ percentiles increased sharply between 1950 and 1970 for blacks, whites, and Hispanics, followed by more modest growth in the 1970s. Since 1980, however, earnings for the three groups have displayed remarkably little change, apart from modest declines in the Great Recession. Earnings at the $90^{\text {th }}$ percentile increased continuously for black, Hispanic, and white men between 1950 and 2000. For all three groups, however, earnings at the $90^{\text {th }}$ percentile were lower in 2010 than in 2000.

In short, the first decade of the $21^{\text {st }}$ century has seen decreased real annual earnings for black, white, and Hispanic men throughout the earnings distribution, modest decreases at the top of the distribution and substantial declines toward the middle and lower portions of the distribution.

\footnotetext{
${ }^{14}$ We subsequently use median regressions to examine logarithmic differences and trends in white-black and whiteHispanic median earnings.
} 


\section{Quantile Regression}

This section uses quantile regression techniques to estimate racial/ethnic differences in log earnings between whites, blacks, and Hispanics both with and without controls for individual age, education, and location. ${ }^{15}$ We first examine differences at the median, and then look at differences throughout the earnings distribution. Median regression is a specific case of quantile regression in which the median of the dependent variable is modeled as a function of one or more explanatory variables. Median and quantile regression have been used in a wide variety of applications in economics and statistics; examples and further details are provided by Buchinsky (1994, 1998), Koenker and Hallock (2001) and Koencker (2005). While most studies of racial differences in earnings use least squares to examine differences in means, a few studies have looked at median differences including Neal and Johnson (1996), Johnson et al. (2000), and Chandra (2003). For estimating racial differences in earnings, median regression offers advantages over least squares because it is less influenced by outliers and reduces issues with imputing non-workers' earnings when those persons' potential earnings are likely to fall below the median (Johnson et al. 2000). More generally, looking at various quantiles, including the median, allows us to examine racial and ethnic differences throughout the earnings distribution.

\subsection{Median Regression Results}

Panel A of Table 2 presents median regression results of log annual earnings for men ages 18-61 in which the only explanatory variables are a dummy variable if the individual is black (or Hispanic) and a constant. White men are the omitted reference group, which allows the coefficients on black and Hispanic to be interpreted as the log point differences in annual earnings between blacks and whites and Hispanics and whites. White, black, and Hispanic men,

\footnotetext{
${ }^{15}$ We redefine all non-positive earnings, including stated losses among self-employed workers, to one dollar so that $\log$ earnings are equal to zero for non-earners. Self-employed workers with losses comprise a trivial fraction of recorded non-earners.
} 
however, differ in age, education, and geographic location, all of which have been shown to influence wage rates and racial/ethnic earnings differences (Black et al. 2009; DuMond et al. 1999). Panel B controls for age by adding a set of 43 dummies for single year of age. Panel C controls for age and education by adding a set of 10 dummies for highest education completed. Panel D also controls for location by adding a full set of dummies for each individual metro area or state non-metro area as done in Black et al. (2009) using least squares regression. ${ }^{16}$ Table 2 results are also illustrated in Figures $4 a-b$.

The results in panel A of Table 2 show that the median log earnings gap for black relative to white men deteriorated between 1950 and 2010, despite substantial progress during the 1960s. ${ }^{17}$ In the first decade of the twenty-first century, black men suffered a major setback in relative earnings. The black-white log earnings gap increased from -0.66 to -0.90 between 2000 and 2006 and then jumped to -1.60 in 2010, substantially larger than in 1950 . The native-born Hispanic-white log earnings gap (without controls) has been stable at around -0.45 since about 1990, prior to its widening in 2009-2010.

Including the detailed controls for age (panel B) reduces the earnings gaps for blacks and Hispanics relative to whites. Adding controls for education (panel C) further reduces estimated gaps, particularly for Hispanics, confirming that a considerable portion (but far from all) of observed racial/ethnic earnings differences is due to age and education differences. For example,

\footnotetext{
${ }^{16}$ The number of identifiable metro areas differs across years and no metro areas were separately identified in the 1960 Census. For 1960 we include dummies for state and state interacted with metropolitan status.

${ }^{17}$ The sample sizes for all groups and years are sufficiently large that all coefficients in Table 2 are statistically significant at the one percent level, so standard errors are not reported. Because imputation flags are missing or incomplete in the 1960 and 1970 Censuses, we are reluctant to rely fully on measured earnings growth during these early decades. Such measures since 1980 should be reliable. Longitudinal Social Security earnings data, matched to the CPS, has established that black gains relative to whites following the Civil Rights Act of 1964 were substantial through 1974, but stalled thereafter (Vroman 1990). In a recent paper, Duleep and Regets (2012) use Social Security earnings data linked to the 1973 CPS (which identified Hispanic as well as racial status), and finds that low income Hispanic as well as black earnings rose significantly relative to whites in the five years following compared to the five years prior to the Civil Rights Act of 1964. The authors' sample omits individuals who did not have Social Security taxed earnings in each of the ten years.
} 
the black coefficients for 2000 and 2010 fall (in absolute value) to -0.47 and -0.90 in panel C, reductions of 0.19 and $0.70 \log$ points relative to the raw (no controls) estimates in panel A. Even controlling for age and education, however, the 2000s has been a tough decade for black men. Controlling for age and education reduces the Hispanic coefficients by even more than for black men. The Hispanic-white gaps for 2000 and 2010 fall to -0.12 and to -0.10 , respectively, reductions of .33 and $.48 \log$ points relative to the gaps absent controls (panel A). Thus, while black men lost considerable ground in the 2000s, Hispanic men largely held their own in earnings relative to non-Hispanic white men.

Including the location controls in panel D has no effect on the 1950 black coefficient, while 1960 results are compromised by the inability to identify individual MSAs. Beginning in 1970, however, adding the location controls increases the black coefficient reflecting the decreasing concentration of blacks in the South and increasing concentration in metro areas (Black et al. 2009; DuMond et al. 1999). The results in panel D indicate that the racial earnings gap increased from -0.52 to -0.97 between 2000 and 2010, confirming again that the relative earnings of black men deteriorated badly in the last decade. For Hispanic men, controlling for location substantially widens estimated log earnings gaps relative to whites because of the relative concentration of Hispanics in high earnings locations. The Hispanic gap (with full controls) changed little between 2000 and 2010, from -0.14 to -0.155 , in sharp contrast to the deterioration seen for black men.

\subsection{Median Regression with Alternative Earnings Measures and Population Samples}

We next examine how blacks and Hispanics did relative to whites in the 2000s using alternative measures of economic activity and earnings. Specifically, we re-estimate the median regressions for 2000 and 2006-2010, shown previously in panel D of Table 2, using three 
alternative dependent variables: log weekly earnings, log hourly earnings, and log annual hours worked. Besides being important economic measures in their own right, examining these additional variables allows us to qualitatively assess each one's contribution to trends in the log annual earnings gap. ${ }^{18}$ The baseline results in panel D of Table 2 for 2000-2010 are reproduced in panel A of Table 3, and results for the three additional measures are reported in panels $\mathrm{B}, \mathrm{C}$, and $\mathrm{D}$ of Table 3. The far right column of Table 3 also reports the change in each measure between 2000 and 2010. These results are visually represented in Figures 5a-b.

Unfortunately, the variable measuring weeks worked the previous year for 2008, 2009 and 2010 is reported only in intervals from 1-13, 14-26, 27-39, 40-47, 48-49, and 50-52 and not on a continuous basis as in 1950-2007. In order to estimate weekly earnings, hourly earnings, and annual hours for 2008-2010, we impute the number of weeks worked based on the reported interval information and the relationship between the actual weeks worked and the corresponding interval in 2007. Specifically, we use the 2007 ACS to compute the mean weeks worked for each interval by race, age, and education level and then assign that mean to persons in 2008-2010 based on these attributes.

Panels A-D of Table 3 suggest that for all outcome measures considered, controlling for age, education, and location, black men lost considerable economic ground relative to white men between 2000 and 2010. The increase in the white-black median gap between 2000 and 2010 is largest for annual earnings, being $0.45 \log$ points. The widening of the white-black gap in weekly earnings is about $12 \log$ points lower but still very large, at 0.33 . White-black median log gaps in hourly earnings and annual hours also increased substantially in these years, by 0.24 and $0.35 \log$ points, respectively. While we view annual earnings as the best measure of the

\footnotetext{
${ }^{18}$ Note that we cannot strictly decompose the changes in median log annual earnings into the changes in median $\log$ hourly earnings and median log annual hours as would be possible using means of the variables. This is because median annual earnings do not generally equal median hourly earnings times median annual hours.
} 
disparity in labor market outcomes between white and black men, its severe deterioration since 2000 was clearly a result of substantial declines in both black hourly earnings and hours worked.

We also consider how results vary using different population samples. We first examine the effects on relative median annual earnings when restricting the sample to men with positive earnings in the previous year, which we refer to as the "worker sample" (panel E). We next look at how results change when we restrict the sample to the non-institutionalized population in the Census and ACS (panel E). ${ }^{19}$ Next we estimate median log earnings gaps for the Census and ACS samples inclusive of foreign born men (panel G), who were excluded from our primary sample. Finally, we examine how the results change when men with imputed earnings are added to our primary sample (panel H). Visually, results from panels A-B-C can be seen in Figure 5c and those from panels A-F-G in Figure 5d.

Over time there has been selective withdrawal from the workforce of low-skilled black men, many or most of whom would have realized low earnings had they worked. Such selection helps account for results for the black-white median annual earnings differences for the sample of workers only (panel E), results that are strikingly different from those seen for our more comprehensive primary sample (panel A). The annual racial earnings gap among wage earners is far lower in every year and the change between 2000 and 2010 , from -0.29 to -0.32 , is not substantive. Looking only at workers and ignoring selection masks the considerable deterioration in relative earnings that the larger population of black men experienced in the 2000s. If the goal is to assess the economic well-being of black men, our preferred sample includes men both with and without paid employment.

\footnotetext{
${ }^{19}$ In work not shown, we compare results from the March Current Population Survey (CPS) and the ACS noninstitutional samples (the CPS does not include the institutional population). The CPS data largely mimic the ACS results, but with more year-to-year variation due to relatively small CPS sample sizes of blacks and Hispanics.
} 
Excluding the institutionalized population also results in measured outcomes being affected by selective withdrawal. Panel $\mathrm{F}$ of Table 3 shows results form a sample restricted to the non-institutionalized population. Doing so has a similar but less extreme effect as does the omission of all non-earners. Between 2000 and 2010 the black coefficient on median log annual earnings changed from -0.48 to -0.73 , an increase in the earnings gap almost half as large as seen for the full sample.

For native-born Hispanic men, the results show that Hispanics maintained their labor earnings relative to whites between 2000 and 2010. Hispanics were harmed by the Great Recession, but not disproportionately so. Interestingly, had foreign-born Hispanics (and whites) been included in the sample, we would have concluded that there had been a 0.07 log point increase in Hispanic-white earnings during the decade, with a narrowing of the gap from -0.18 to -0.11. This seemingly anomalous result occurs because the foreign-born Hispanic population saw little change in its non-earnings rate (perhaps because of migration flows), while the nonearnings share for native-born Hispanics increased from 0.17 to 0.24 . In short, earnings growth among native Hispanic men mirrored that of the native white male population.

\subsection{Sensitivity to Imputed Earners}

Panel $\mathrm{H}$ of Table 3 examines how the inclusion of imputed earners in the median regression analysis affects results. Including men with imputed earnings has only a modest effect on the results for the 2000 Census, where the extremely large sample sizes appear to provide high quality matches. In sharp contrast, inclusion of imputed values in the much smaller ACS produces far poorer donor quality matches for African Americans, resulting in considerable attenuation in the black coefficient. ${ }^{20}$ In 2010, inclusion of imputed earners causes attenuation in

\footnotetext{
${ }^{20}$ The Census 2000 long-form survey was distributed to one sixth of the U.S. population, but the 2010 ACS surveyed less than two percent of the U.S. population. For both surveys only a subset of the full sample was
} 
the black coefficient, from -0.97 to -0.76 , indicating that there is considerable match bias in imputed earnings for black men.

The importance of imputed earner bias can also be seen by examining the share of nonearners using alternative treatments of imputed earners. Panel A of Table 4 reports the nonearner share for 2000-2010 for our primary sample, which excludes imputed earners and reweights the respondent sample to account for the probability of earnings non-response. Panel B reports the share of non-earners for our primary sample with no reweighting for the probability of non-response. Panel $\mathrm{C}$ reports the share for a full sample including both respondents and imputed earners. Panel D reports the share for a sample including only imputed earners. Panels $\mathrm{A}$ and $\mathrm{B}$ are similar, confirming that reweighting based on the probability of non-response is a second-order issue. The small differences between panels A and B indicate that non-respondents have observable characteristics associated with a lower probability of positive earnings.

Comparing panels $\mathrm{A}$ and $\mathrm{D}$ (or B and D), it is readily evident that both the Census and ACS assign too few non-earning donors to non-respondents. This is a particularly serious issue for the ACS. For example, using the 2000 Census, the 0.21 share of black non-earners in the imputed sample (panel D) is "only" 0.07 share points lower than in the unweighted sample of black respondents (panel B). Using the full sample (panel C) there is only a "modest" downward bias of 0.04 in the estimated share of non-earners, 0.25 with the full sample (panel B) versus 0.29 in our reweighted respondent sample (panel A). Using the ACS, however, downward bias in the black non-earnings share is more substantial. For each of the years 2006 through 2009, bias is 0.06 to 0.07 . In 2010, the downward bias is 0.08 points, a black non-earnings share of 0.34 in the full sample versus the 0.42 reported for the reweighted respondent sample. The substantial percent samples of the population, but the Census sample is a subset of a much larger sample, which provides a much larger pool of potentially well-matched earnings donors for the non-respondent sample. 
bias in the 2010 median regression black coefficient when imputed earners are included is due primarily to the low rate at which non-respondents are assigned non-earning donors. Only 14 percent of black non-respondents are allocated zero earnings. Imputation bias also exists for whites and Hispanics. For white, black, and Hispanic men in the ACS, the non-earner rates for imputed earners are about one-third the rates for respondents (Table 4, panel D versus A or B).

In short, including non-respondents with imputed earnings substantially understates the share of non-earners and the median log earnings gap between black and white men. In addition to biasing estimated levels of the racial earnings gap, use of samples that include imputed earners affects estimates of changes in the gap, considerably understating the deterioration in black relative earnings between 2000 and 2010. These results highlight the importance of excluding imputed earners from analyses of levels and changes in relative earnings. ${ }^{21}$

\subsection{Quantile Regression Results throughout the Distribution}

Racial and ethnic differences in median log annual earnings are important, but may not accurately reflect earnings gaps at other points in the earnings distribution. Thus, we use quantile regression to examine racial and ethnic differences in log annual earnings at different points in the distribution. Table 5 reports quantile regression log annual earnings gaps for blacks and Hispanics relative to whites with full controls for age, education, and location at the $30^{\text {th }}$ through $90^{\text {th }}$ deciles for 2000 and 2010 . Results for the $10^{\text {th }}$ and $20^{\text {th }}$ percentiles are not reported because the very high non-earner rates at the lowest percentiles render such estimates uninformative.

\footnotetext{
${ }^{21}$ The alternative to exclusion of imputed values is to apply one's own "full information" imputation procedure or to explicitly model selection into response. Bollinger and Hirsch (2006, forthcoming) show that exclusion of imputed earners is a reasonable, low-cost estimation approach for most wage analyses.
} 
In both 2000 and 2010, white-black earnings gaps decline as we move toward the upper ends of the earnings distributions. ${ }^{22}$ For the year 2000, for example, the earnings gap is -0.69 at the $40^{\text {th }}$ percentile, -0.44 at the $60^{\text {th }}$ percentile, and -0.36 at the $80^{\text {th }}$ percentile. This pattern becomes more evident over time, the increase in the white-black earnings gap between 2000 and 2010 being largest at the lower deciles and smallest at the higher deciles. For example, between 2000 and 2010 the earnings gap at the $50^{\text {th }}$ percentile expanded (in absolute value) by $0.44 \log$ points, but gap widening declined as one moves up the earnings distribution, with increases of $0.24,0.11$, and $0.08 \log$ points at the $60^{\text {th }}, 80^{\text {th }}$, and $90^{\text {th }}$ percentiles. So while black men saw their annual earnings decline relative to whites at all parts of the distribution, the effects are most pronounced for the least-skilled and lower-earnings African Americans. Such a pattern underscores the importance of examining racial earnings differences throughout the distribution. Hispanic-white log annual earnings gaps are substantially smaller than black-white gaps at every point in the distribution in both 2000 and 2010. That is, conditional on age, education, and location, Hispanics are faring better than are African Americans throughout the earnings distribution. In contrast to black male earnings, Hispanic relative to white male earnings varies little throughout the top two-thirds of the earnings distribution. At the $40^{\text {th }}$ percentile and above, Hispanic-white earnings gaps are in the mid-teens and increased little (1 or 2 percentage points) between 2000 and 2010. As seen previously for median earnings, changes in earnings during the past decade among native Hispanic men throughout the wage distribution largely mimicked

\footnotetext{
${ }^{22}$ The relative earnings trend is likely related to the increasing non-employment of black men in a complicated way. The significant decline in black earnings at the lower end of the distribution is no doubt partly responsible for increased non-employment rates. At the same time, some men who withdraw from the labor market may not have had potential earnings at the very bottom of the distribution, thus their non-employment decreases observed earnings at the lower-middle part of the earnings distribution. Untangling the simultaneous effects of declining offer wages and declining employment rates is a tricky issue and beyond the scope of this paper. Instead, we present descriptive evidence to help gauge the relative economic disparities of black men and how they have changed over time.
} 
performance among white men. Across the entire distribution, the performance of Hispanic men was notably better than that seen among black men.

\section{Rounding, Heaping, and Smoothing}

A common attribute of household surveys is that for continuous variables such as annual earnings, respondents report numbers that are rounded and concentrated (heaped) at focal values. In the case of earnings, most reported earnings have a last digit of zero, with greater heaping of values ending in two zeroes than in one, three than two, four than three, and five than four, plus a heaping of reported earnings half way between focal values (e.g., more reports at $\$ 35,000$ than at $\$ 31,000$ through $\$ 34,000$ or $\$ 36,000$ through $\$ 39,000)$. For some if not most analyses, rounding is not a problem, particularly if the data are "coarsened at random," largely analogous to data missing at random (Heitjan and Rubin 1990, 1991). Within a regression framework, it matters whether or not the randomly coarsened variable is on the left-hand side or right-hand side (Hausman 1991). If coarsened earnings are used to measure a right-hand side variable, its coefficient is attenuated due to measurement error. This should not be serious as long as the degree of rounding is small relative to the true variation in earnings. If the coarsened variable is on the left-hand side, as in our analysis, then such measurement (reporting) error should not bias coefficients, but it will lower the equation goodness of fit and increase standard errors.

It is less clear how coarsened earnings might affect estimates using quantile analysis. Given the extent of heaping in the earnings data, we were concerned that median regression coefficient estimates (or those at other quantiles) might exhibit "jumps" due to movements from one large heap of earnings to another. To examine this issue, we smoothed the earnings data heaped at rounded values. For all earnings whose value ended in two or more zeroes, we calculated a pseudo random value generated using a standard normal distribution. We then 
added to each reported earnings value an amount equal to the random value times 20 percent of the rounded value (e.g., 200 if rounded to the nearest $\$ 1,000$ or 2000 if rounded to the nearest $\$ 10,000)$. This procedure distributes heaped earnings without affecting the mean.

Despite our concerns, the analysis indicates that estimates are insensitive to heaping of earnings at values ending with zeroes (these estimates are available on request). Descriptive data showing black, Hispanic, and white earnings at various percentiles displayed minimal effects from smoothing. Using the smoothed earnings data, coefficient estimates from median regression (and from other quantiles) are highly similar to those reported in the paper. Because estimates are so similar with and without the use of smoothed data, we report only results using the reported earnings values.

\section{Conclusion}

This paper presents an anatomy of earnings differentials and trends for white, black, and Hispanic men, with a particular focus on differentials between 2000 and 2010. Using data from the decennial census and American Community Survey, we find that native Hispanic men largely held their own in earnings relative to whites during the 2000s throughout most of the earnings distribution. Had the analysis included the foreign-born Hispanic population, for whom nonearnings shares showed little deterioration, one would have seen modest closing in the Hispanicwhite earnings gap. For black men, however, the first decade of the new millennium has been a difficult one along a number of dimensions, especially for less-skilled blacks. First, the share of prime-age black men with no earned income over a year rose from a high 29 percent in 2000 to an even higher 42 percent in 2010. Median annual earnings for black men declined both in real dollars and relative to whites and Hispanics. The median log annual earnings differential between whites and blacks in 2010 was larger than at any time since at least 1950, with or 
without controls for age, education, and location. Black men are losing ground economically, a discouraging pattern seen prior to and greatly exacerbated by the Great Recession.

The analysis also has focused on important measurement issues, in particular the sensitivity of estimates with respect to the treatment of non-earners and accounting for imputed earnings. Concern that quantile estimates might be sensitive to heaped earnings (i.e., reporting at rounded numbers) in household data sets turned out to be unfounded. Trends in Hispanic earnings are found to be sensitive to the inclusion of the foreign-born population.

The sharp deterioration in employment outcomes for black men leads naturally to questions about appropriate policy responses. Although analysis of policies goes well beyond the scope of this paper, some general suggestions seem warranted. First and foremost, it is clear that a healthy and robust macro-economy is essential for improving the relative well-being of African Americans. Even substantial improvements in economic growth cannot quickly undo the economic damage seen since 2008. Although not sufficient, a robust labor market is certainly a necessary condition for increased black male labor force participation and earnings growth. More controversial and politically difficult would be explicit public sector creation of jobs that benefit individuals marginalized in today's labor market due to low skills and changes in technology.

Equally fundamental will be substantial improvements in the accumulation of cognitive and noncognitive human capital among black youth, improvements that can later narrow the gaping racial gaps in labor market outcomes. Although there are no magic bullets, programs that target young children can meaningfully narrow racial gaps in cognitive skills, while progress in narrowing noncognitive skill gaps may be achievable even among older age groups (Heckman 2011). The benefit from narrowing cognitive skill gaps are readily seen in our evidence on racial 
gaps by schooling level. Much of the benefit results through enhanced labor force participation, the movement from being a black male high school dropout to a college graduate in 2010 reducing the probability of having no earned income from 0.72 to 0.12 . Increasing human capital stocks may result from traditional policies such as making college more affordable, as well as non-traditional policies such as paying students for getting good grades, reading books, or graduating from high school (Fryer 2011). Ideally, policies that increase human capital will benefit all demographic groups, but disproportionately so for young black men.

In addition to human capital deficiencies, criminal activity and the U.S. correctional system play a major role in the economic woes of black men (Pettit 2012; Western and Pettit 2005; Raphael 2006). Young men typically enter the correctional system at a young age and are exposed to hardened criminals and an environment that discourages investment in skills valued in the formal labor market. When they are released, a criminal record reduces the ability to obtain legal employment (Holzer et al. 2005). Many end up reoffending and spend their lives in and out of jails and prisons and consistently out of the labor force. While we do not offer specific solutions to the problems with the U.S. correctional system (e.g., reexamining penalties for drug offenses), we are confident there has to be a better way.

It has long been known that economic outcomes among black men are relatively poor as compared to those for white men. We have shown in this paper that racial gaps in earnings are larger than widely recognized and that the relative well-being of black men has badly deteriorated during the Great Recession. The proximate explanation for much of this racial gap is the low employment rate among less-educated black males. Although there are few easy remedies to undo the damage or substantially reduce the size of racial gaps, the goal of reducing racial disparities deserves no small degree of urgency. 


\section{References}

Altonji, Joseph G. and Rebecca M. Blank, 1999. "Race and Gender in the Labor Market," in Orley C. Ashenfelter and David Card, eds., Handbook of Labor Economics. Volume 3C. Chap. 48. Amsterdam: North Holland, 3143-259.

Antecol, Heather, and Kelly Bedard, 2004. "The Racial Wage Gap: The Importance of Labor Force Attachment Differences across Black, Mexican, and White Men," Journal of Human Resources, 39(2), 564-583.

Baum-Snow, Nathaniel and Derek Neal, 2009. "Mismeasurement of Usual Hours Worked in the Census and ACS," Economics Letters, 102(1), 39-41.

Black, Dan A., Kolesnikova, Natalia, Sanders, Seth and Taylor, Lowell J., 2009. "The Role of Location in Evaluating Racial Wage Disparity,” Working Paper 2009-043B, Federal Reserve Bank of St. Louis.

Black, Dan A., Kolesnikova, Natalia, and Taylor, Lowell J., 2010. "The Economic Progress of African Americans in Urban Areas: A Tale of 14 Cities," Federal Reserve Bank of St. Louis Review, 92(5), 353-79.

Bollinger, Christopher R. and Barry T. Hirsch. 2006. "Match Bias from Earnings Imputation in the Current Population Survey: The Case of Imperfect Matching," Journal of Labor Economics, 24(3), 483-519.

Bollinger, Christopher R. and Barry T. Hirsch, forthcoming. "Is Earnings Nonresponse Ignorable?" Review of Economics and Statistics.

Borjas, George J., Jeffrey Grogger, and Gordon H. Hanson, 2010. "Immigration and the Economic Status of African-American Men," Economica, 77, 255-282.

Bound, John and Richard B. Freeman, 1992. "What Went Wrong? The Erosion of Relative Earnings and Employment among Young Black Men in the 1980s," Quarterly Journal of Economics, 107(1), 201-32.

Brown, Charles, 1984. "Black-White Earnings Ratios Since the Civil Rights Acts of 1964: The Importance of Labor Market Dropouts," Quarterly Journal of Economics, 99(1), pp. 31-44.

Brueckner, Jan K. and Yves Zenou, 2003. "Space and Unemployment: The Labor-Market Effects of Spatial Mismatch," Journal of Labor Economics, 21(1), 242-262.

Buchinsky, Moshe, 1994. "Changes in the U.S. Wage Structure 1963-1987: Application of Quantile Regression,” Econometrica 62(2), 405-458

Buchinsky, Moshe, 1998. "Recent Advances in Quantile Regression Models: A Practical Guideline for Empirical Research,” Journal of Human Resources, 33(1), 88-126.

Butler, Richard and James J. Heckman, 1977. "The Government's Impact on the Labor Market Status of Black Americans: A Critical Review," in L. Hausman et al., eds. Equal Rights and Industrial Relations, Madison, WI: Industrial Relations Research Association.

Chandra, Amitabh, 2000. "Labor Market Dropouts and the Racial Wage Gap, 1940-1990," American Economic Review, 90(2), 333-338.

Chandra, Amitabh, 2003. "Is the Convergence in the Racial Wage Gap Illusory?" National Bureau of Economic Research Working Paper 9476.

Couch, Kenneth and Mary C. Daly, 2002. "Black-White Wage Inequality in the 1990s: A Decade of Progress," Economic Inquiry, 40(1), 31-41.

Duleep, Harriet Orcott and Mark Regets, 2012. "The Civil Rights Act and the Earnings of Lower Income Hispanic Men in the 1960s,” IZA D.P. 6638, June. 
DuMond, J. Michael, Barry T. Hirsch, and David A. Macpherson, 1999. "Wage Differentials across Labor Markets and Workers: Does Cost of Living Matter?” Economic Inquiry, 37(4), 577-598.

Ewing, Bradley T., William Levernier and Farooq Malik, 2002. "The Differential Effects of Output Shocks on Unemployment Rates by Race and Gender," Southern Economic Journal 68(3), 584-599.

Fryer, Roland G. Jr., 2011. "Financial Incentives and Student Achievement: Evidence from Randomized Trials." Quarterly Journal of Economics, Forthcoming.

Fryer, Roland G. Jr., Devah Pager, and Jörg L. Spenkuch, 2011. "Racial Disparities in Job Finding and Offered Wages," NBER Working Paper 17462, September.

Hausman, Jerry, 2001. "Mismeasured Variables in Econometric Analysis: Problems from the Right and Problems from the Left." Journal of Economic Perspectives 15(4), 57-67.

Heckman, James J., 2011. "The American Family in Black and White: A Post-Racial Strategy for Improving Skills to Promote Equality,” IZA D.P. 5495, February.

Heitjan, Daniel F., and Donald B. Rubin, 1990. "Inference from Coarse Data Via Multiple Imputation with Application to Age Heaping." Journal of the American Statistical Association 85(410), 304-314.

Heitjan, Daniel F., and Donald B. Rubin, 1991. "Ignorability and Coarse Data." Annals of Statistics 19(4), 2244-2253.

Holzer, Harry, 1991. "The Spatial Mismatch Hypothesis: What Has the Evidence Shown?" Urban Studies 28(1), 105-122.

Holzer, Harry J., Paul Offner, and Elaine Sorensen, 2005. "Declining Employment among Young Black Less-Educated Men: The Role of Incarceration and Child Support," Journal of Policy Analysis and Management, 24(2), 329-350.

Hoynes, Hilary W., Douglas L. Miller, and Jessamyn Schaller, 2012. "Who Suffers During Recessions?" NBER Working Paper No. 17951, March.

Ihlanfeldt, Keith R., and David L. Sjoquist, 1998. "The Spatial Mismatch Hypothesis: A Review of Recent Studies and Their Implications for Welfare Reform," Housing Policy Debate, 9(4), 849-92.

Johnson, William, Yuichi Kitamura, and Derek Neal, 2000. "Evaluating a Simple Method for Estimating Black-White Gaps in Median Wages," American Economic Review, 90(2), 339-343.

Juhn, Chinhui, 2003. "Labor Market Dropouts and Trends in the Wages of Black and White Men," Industrial and Labor Relations Review, 56(4), 643-662.

Lillard, Lee, James P. Smith, and Finis Welch. "What Do We Really Know about Wages? The Importance of Nonreporting and Census Imputation," Journal of Political Economy 94 (June 1986): 489-506.

Kim, Marlene, 2009. "Race and Gender Differences in the Earnings of Black Workers," Industrial Relations, 48(3), 466-488.

Koenker, Roger, 2005. Quantile Regression, Cambridge University Press: Cambridge.

Koenker, Roger and Kevin F. Hallock, 2001. "Quantile Regression,” Journal of Economic Perspectives, 15(4), 143-156.

Lang, Kevin and Jee-Yeon K. Lehmann, 2011. "Racial Discrimination in the Labor Market: Theory and Empirics," NBER Working Paper No. 17450, September. 
Margo, Robert A., 1995. "Explaining Black-White Wage Convergence, 1940-1950," Industrial and Labor Relations Review, 48(3), 470-481

McLennan, Michele C., 2003. "Labor Market Conditions and the Economic Status of Black Men: A Note." Industrial Relations, 42(1), 78-85.

Mok, Wallace and Zahra Siddique, 2011. "Racial and Ethnic Inequality in Employer Provided Fringe Benefits," IZA D.P. 6255.

Neal, Derek, 2006. "Why Has Black-White Skill Convergence Stopped?" in Eric A. Hanushek and Finis Welch, eds., Handbook of the Economics of Education, Volume 1, Elsevier, 511-576.

Neal, Derek A. and William R. Johnson, 1996. "The Role of Premarket Factors in Black-White Wage Differences," Journal of Political Economy 104, 869-895.

Pettit, Becky, 2012. Invisible Men: Mass Incarceration and the Myth of Black Progress, Russell Sage: New York.

Raphael, Steven, 2006. "The Socioeconomic Status of Black Males: The Increasing Importance of Incarceration," in Alan Auerbach, David Card, and John Quigley (eds.), Poverty, the Distribution of Income, and Public Policy, Russell Sage Foundation: New York.

Raphael, Steven and Michael A. Stoll, 2009. "Why Are So Many Americans in Prison?" in Steven Raphael and Michael A. Stoll, eds., Do Prisons Make Us Safer?: The Benefits and Costs of the Prison Boom, New York: Russell Sage Foundation, 27-72.

Ritter, Joseph A. and Lowell J. Taylor, 2011. "Racial Disparity in Unemployment," Review of Economics and Statistics, 93(1), 30-42.

Robinson J. Gregory, Kirsten K. West, and Arjun Adlakha, 2002. "Coverage of the Population in Census 2000: Results from Demographic Analysis," Population Research and Policy Review, 21(1-2), 19-38.

Ruggles, Steven J., Trent Alexander, Katie Genadek, Ronald Goeken, Matthew B. Schroeder, and Matthew Sobek, 2010. Integrated Public Use Microdata Series: Version 5.0 [Machine-readable database]. Minneapolis: University of Minnesota.

Smith, James P. and Finis Welch, 1989. "Black Economic Progress After Myrdal," Journal of Economic Literature, 27(2), 519-564.

Vroman, Wayne, 1990. “Black Men's Relative Earnings: Are the Gains Illusory?" Industrial and Labor Relations Review, 44(1), 83-98.

Western, Bruce, and Becky Pettit, 2005. "Black-White Wage Inequality, Employment Rates, and Incarceration," American Journal of Sociology, 111(2), 553-78.

Wooldridge, Jeffrey M., 2002. Econometric Analysis of Cross Section and Panel Data, Cambridge: MIT Press.

Wolff, Edward N., Ajit Zacharias, and Thomas Masterson, 2012. "Trends in American Living Standards and Inequality, 1959-2007," Review of Income and Wealth, 58 (2), 197-232. 
Fig. 1: Share of Non-Earners by Race/Ethnicity, 1950-2010

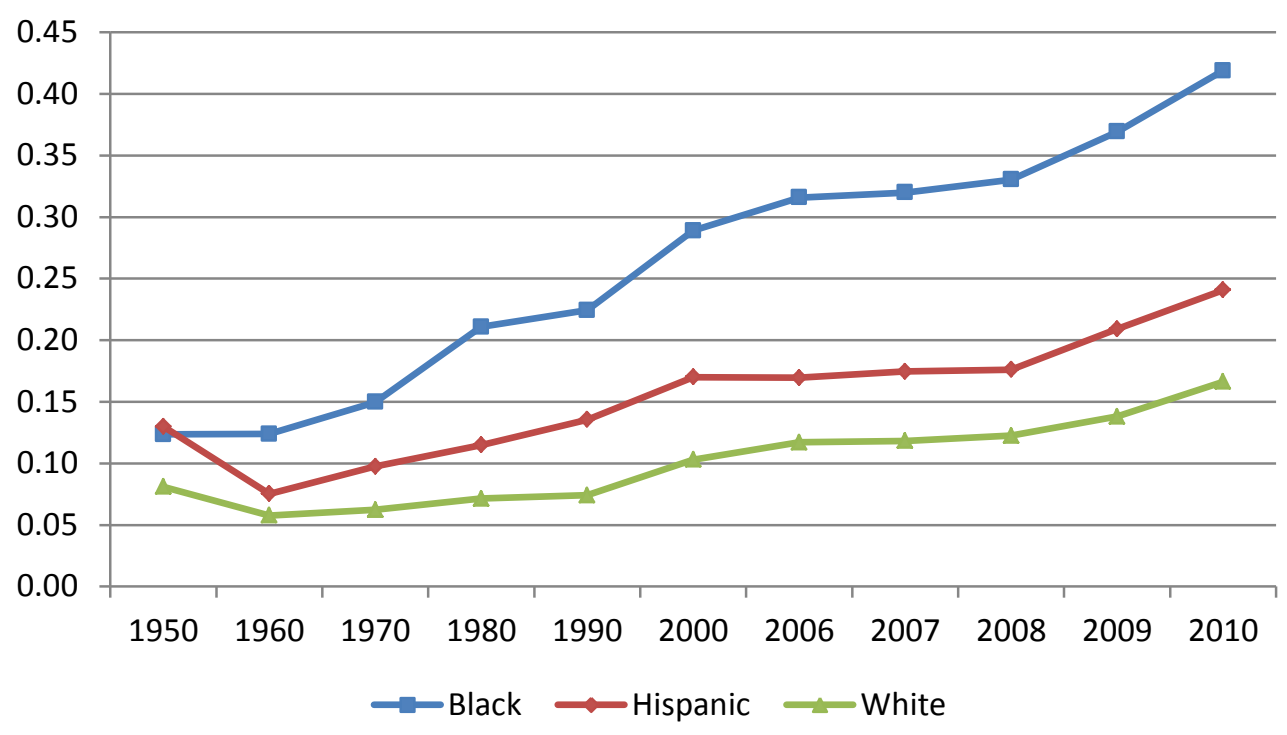


Fig. 2a: Share of Black Non-Earners by Age, 2000 and 2010

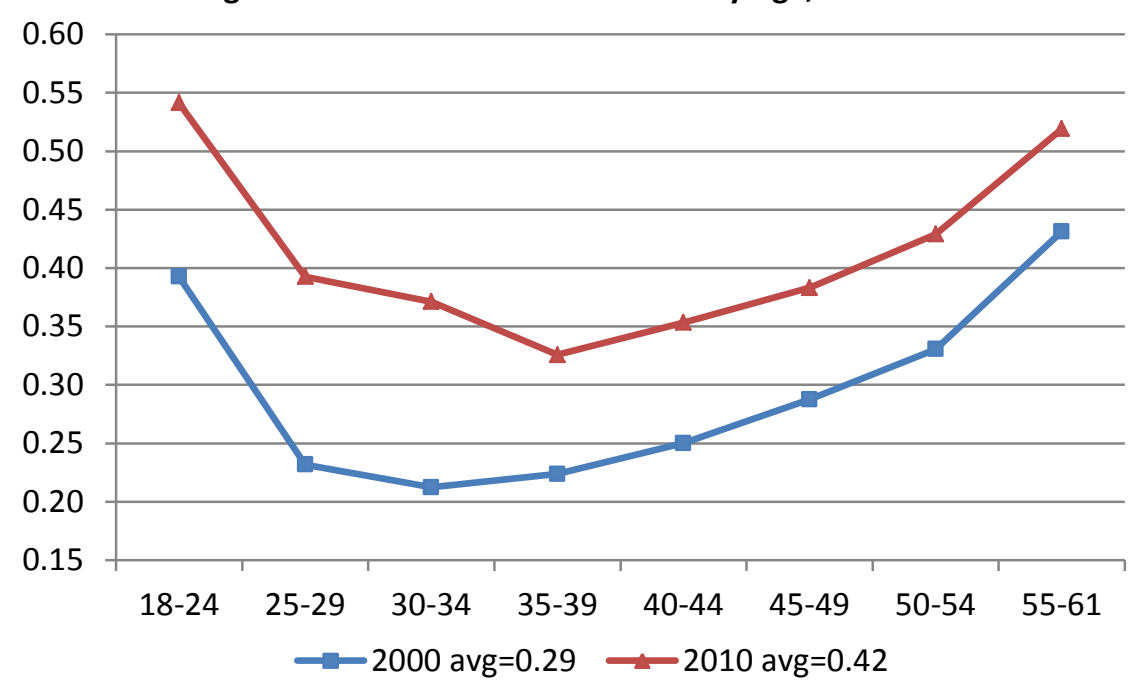

Fig. 2c: Share of Hispanic Non-Earners by Age, 2000 and 2010

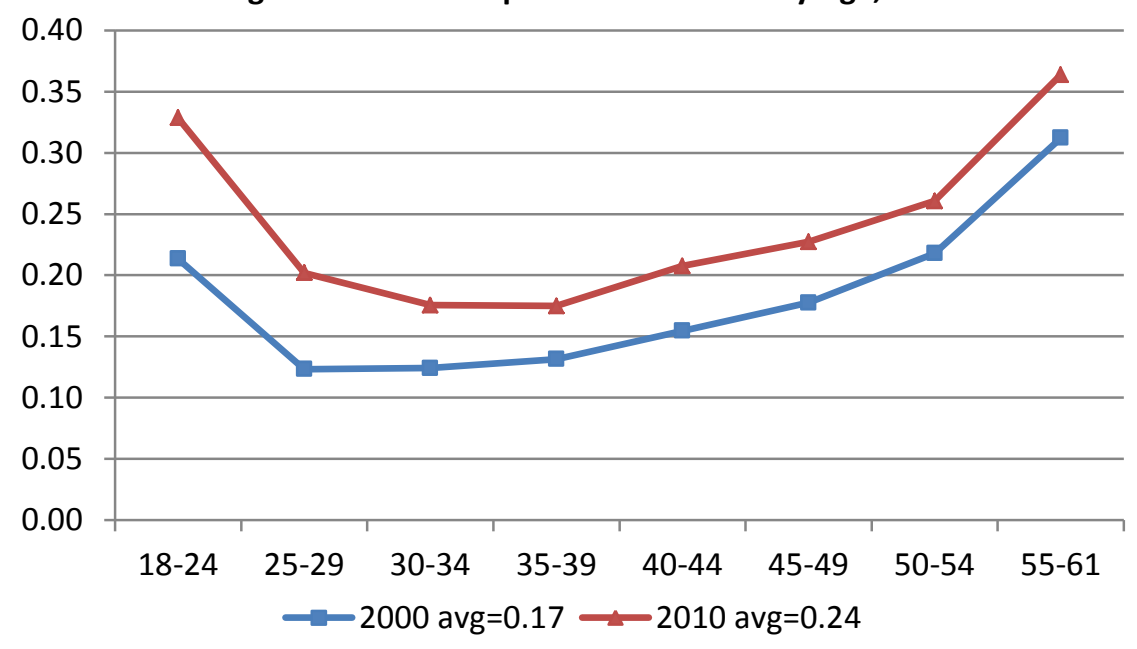

Fig. 2b: Share of Black Non-Earners by Education, 2000 and 2010

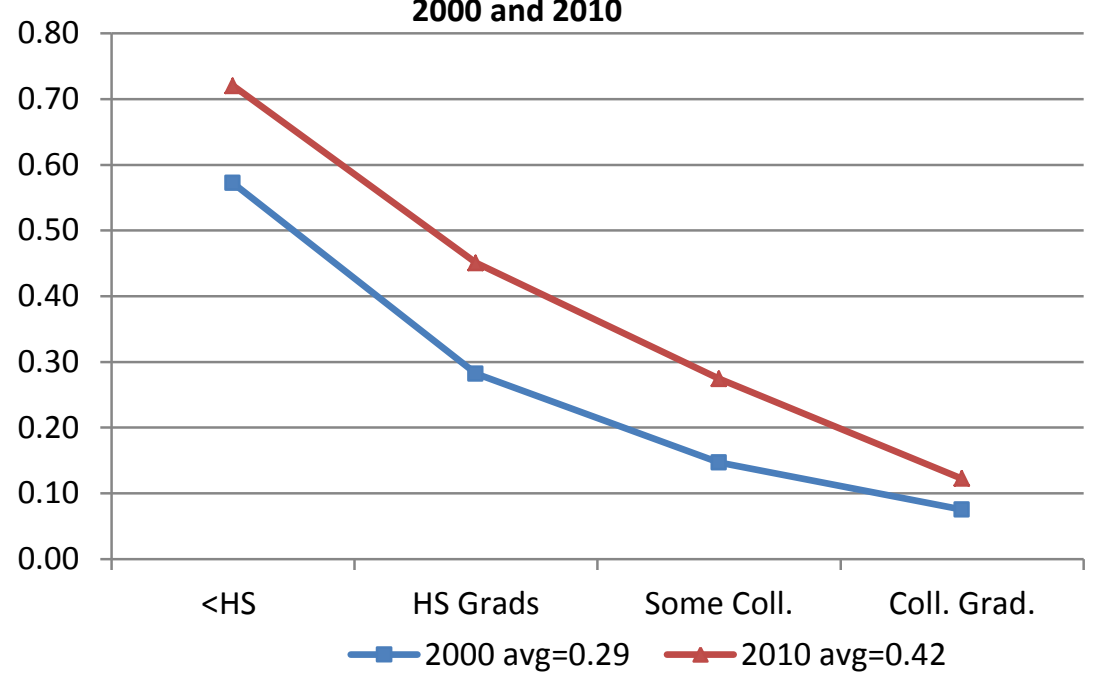

Fig. 2d: Share of Hispanic Non-Earners by Education, 2000 and 2010

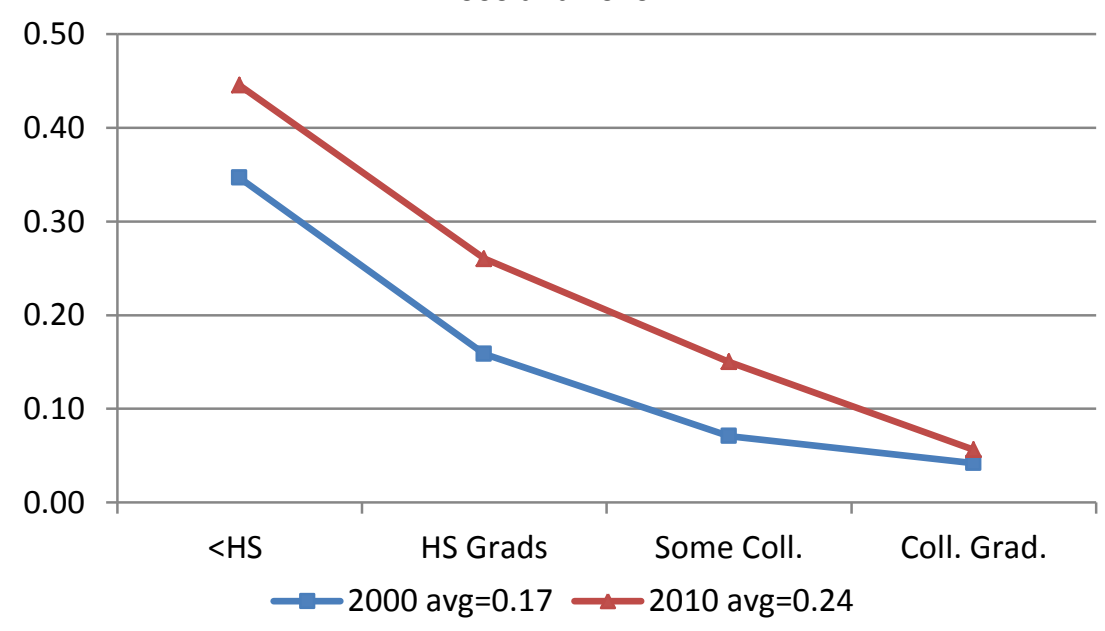




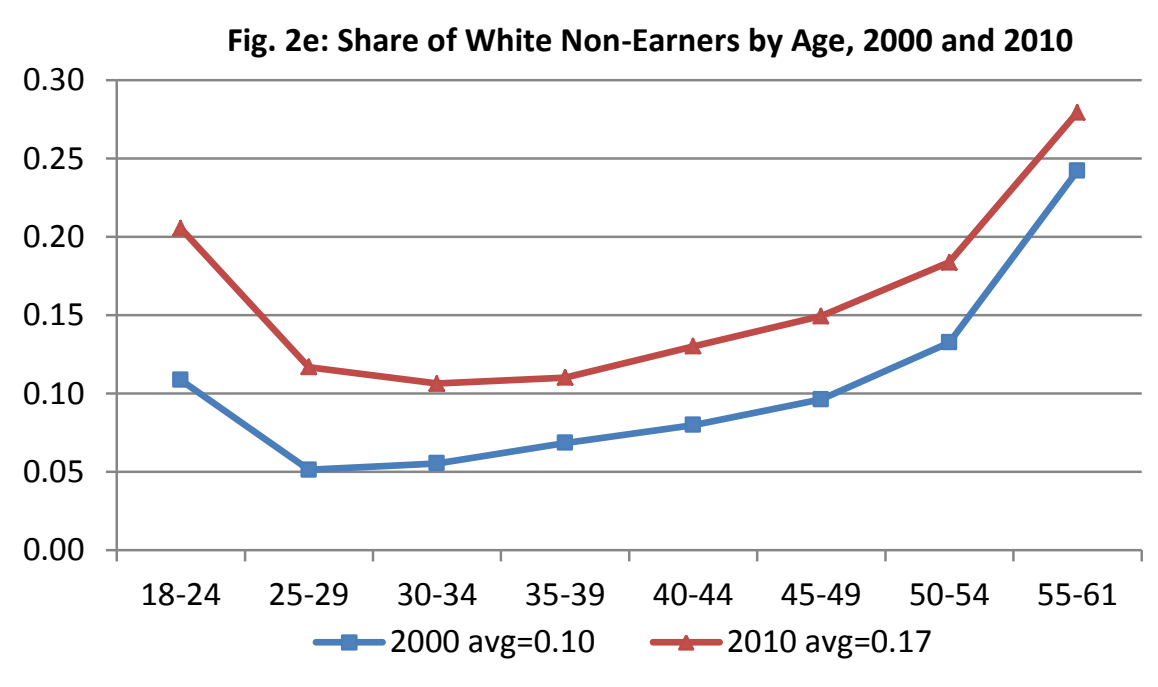

Fig. 2f: Share of White Non-Earners by Education, 2000 and 2010

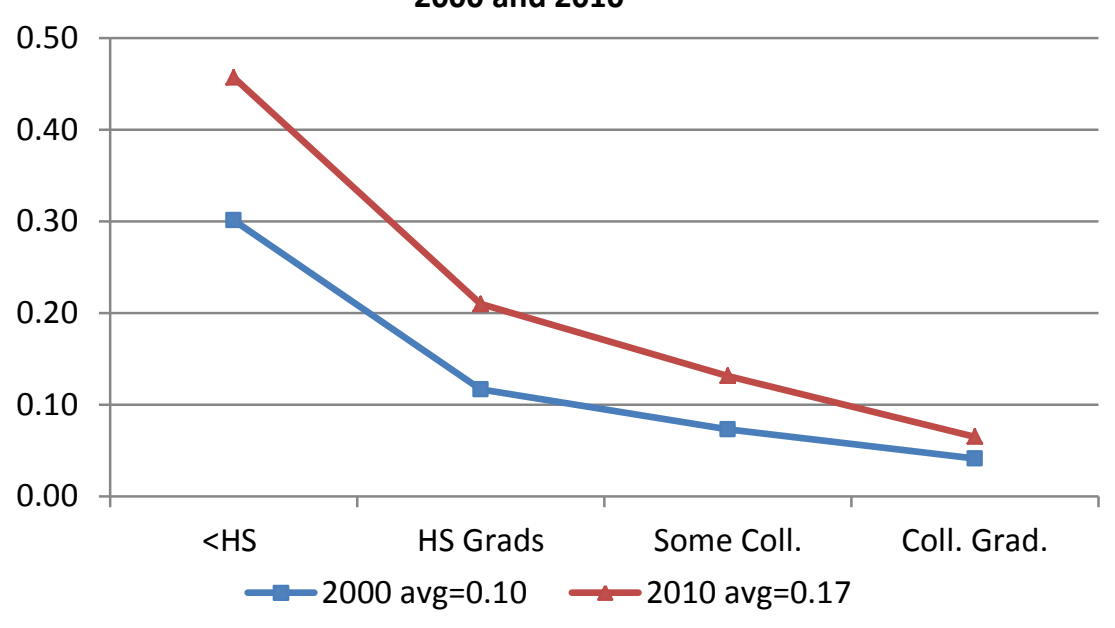




\section{Fig. 3a: Annual Earnings at 25th Percentile, 1950-2010}

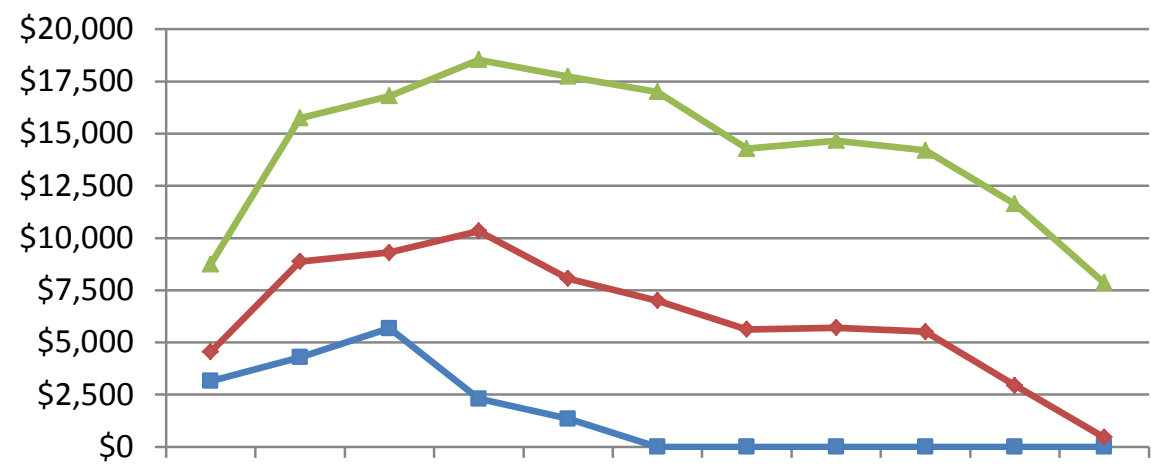

19501960197019801990200020062007200820092010

$$
- \text { Black } \rightarrow \text { Hispanic } \leftarrow \text { White }
$$

Fig. 3c: Annual Earnings at 75th Percentile, 1950-2010

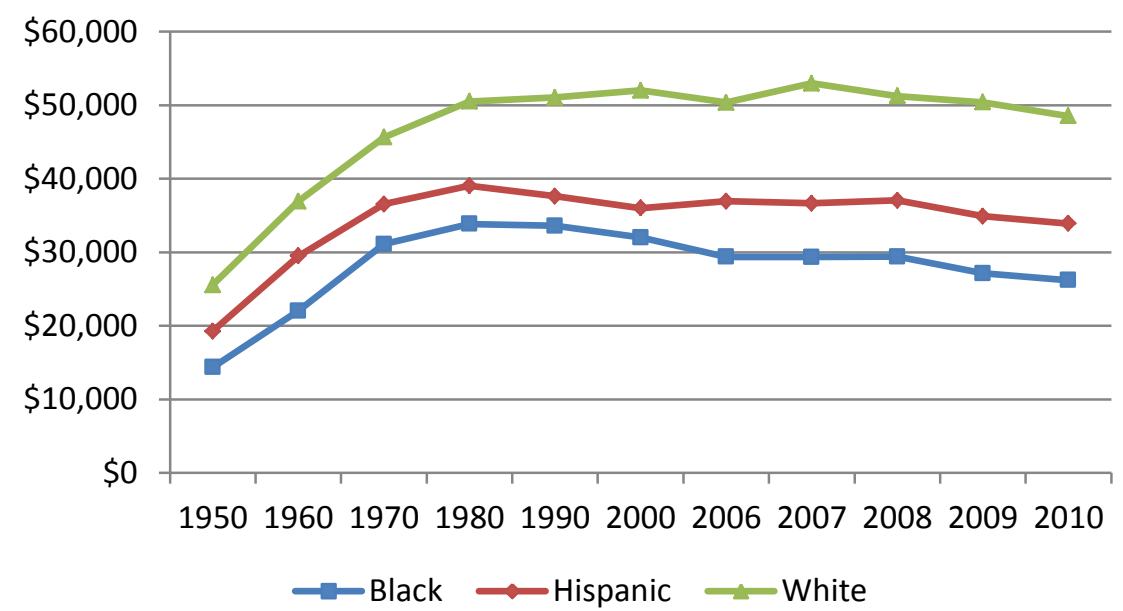

\section{Fig. 3b: Annual Earnings at 50th Percentile, 1950-2010}

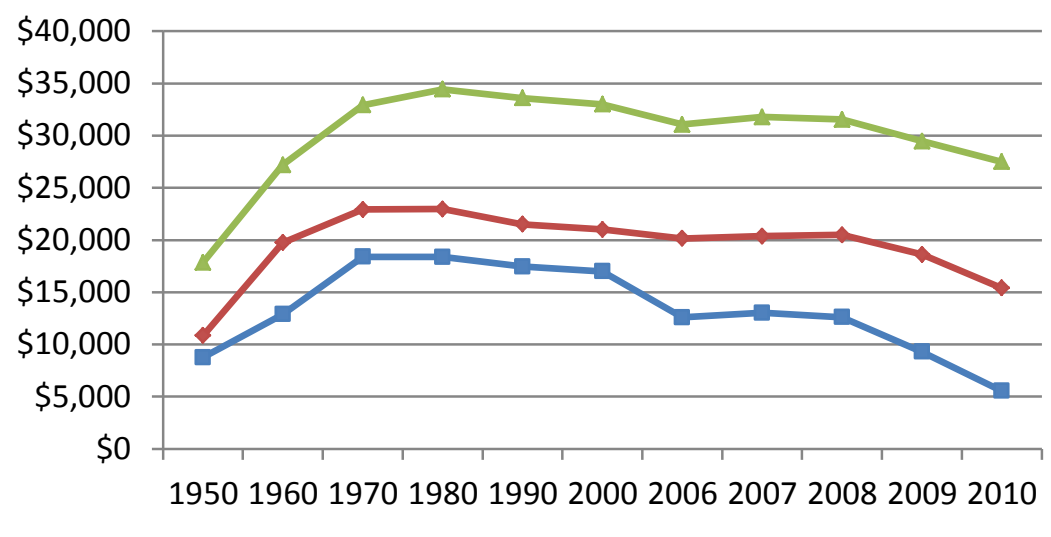

- Black $\leadsto$ Hispanic $\simeq$ White

Fig. 3d: Annual Earnings at 90th Percentile, 1950-2010

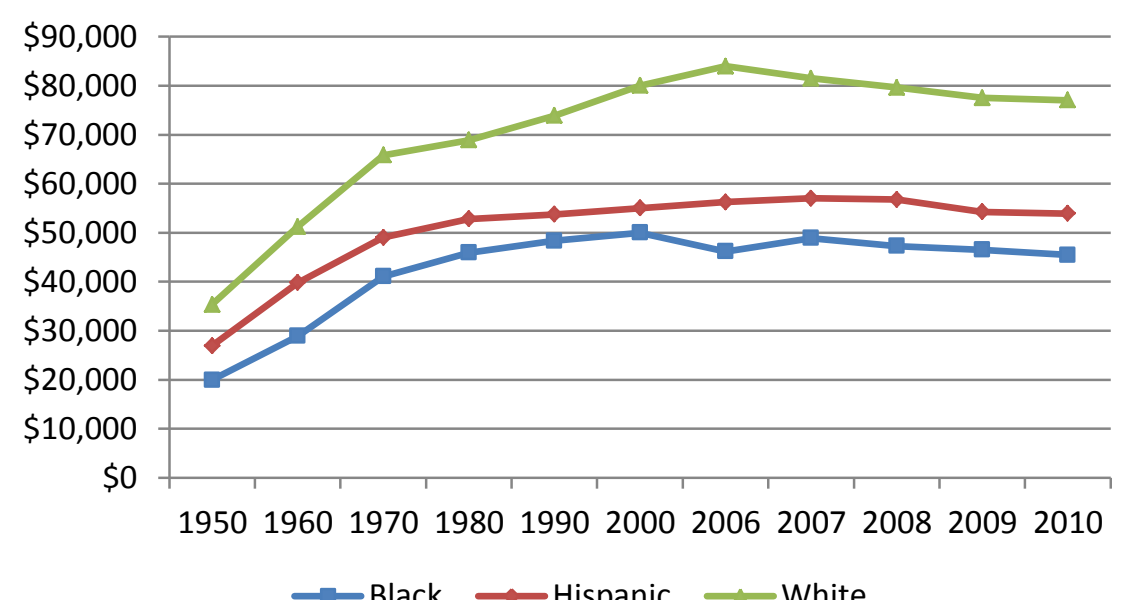


Fig. 4a: Black-White Median Regression Log Annual Earnings Differentials with Alternative Controls, 1950-2010

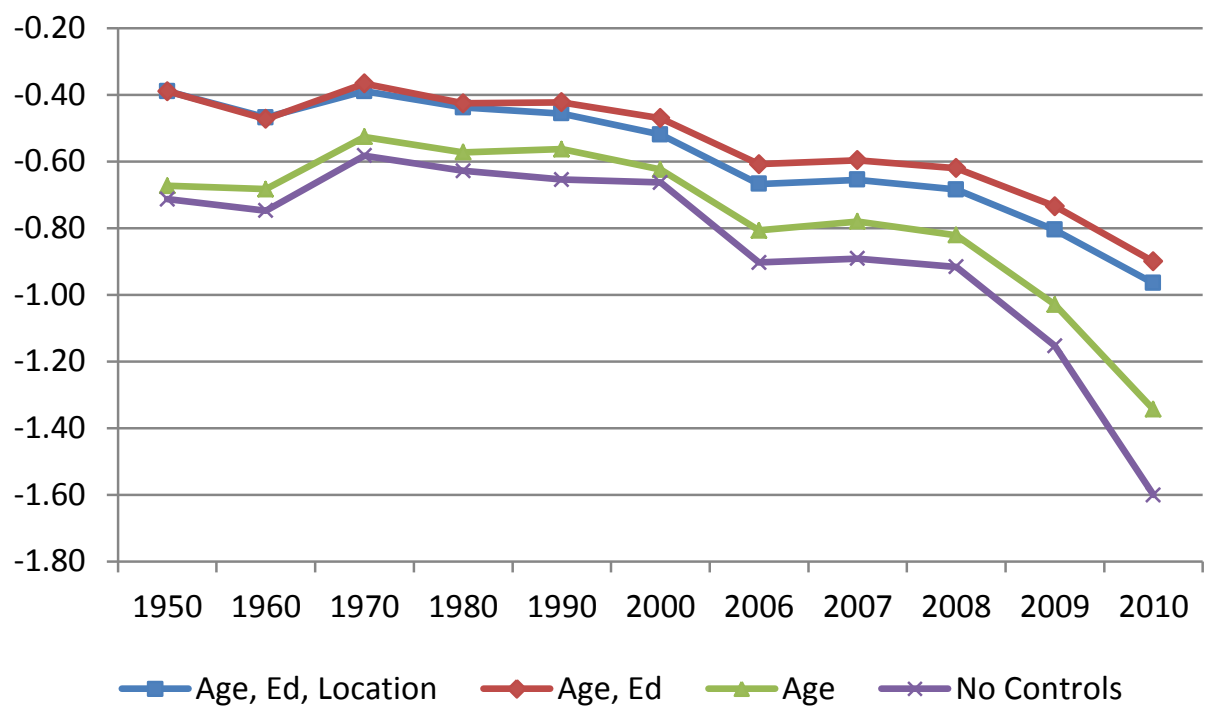

Fig. 4b: Hispanic-White Median Regression Log Annual Earnings Differentials with Alternative Controls, 1950-2010

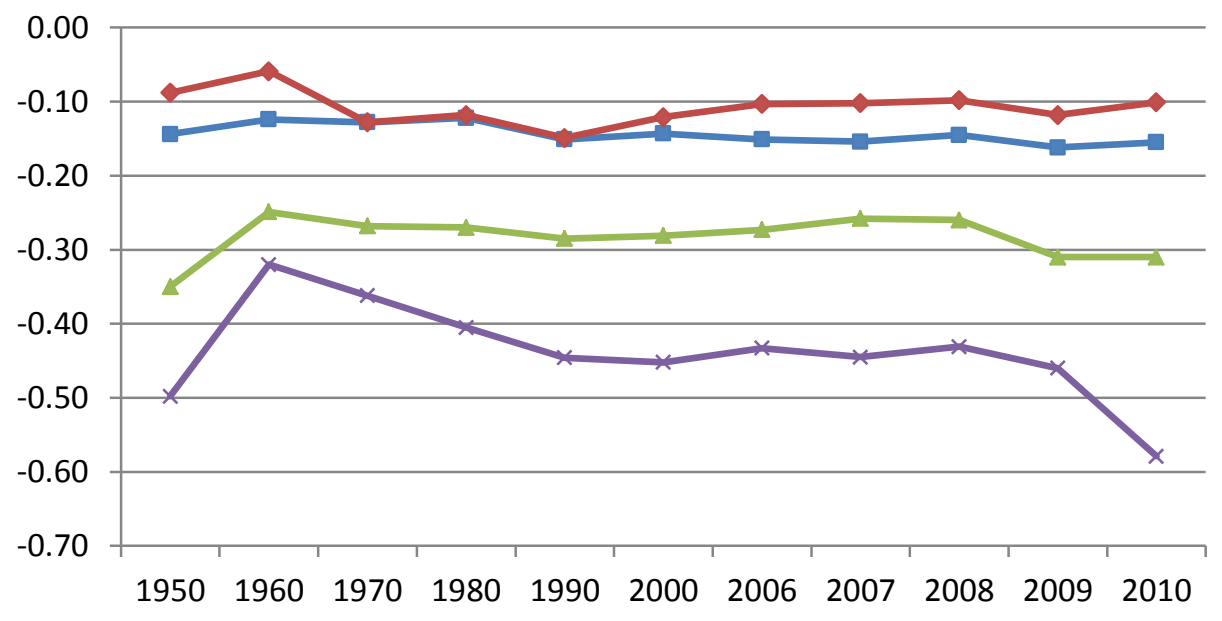

$\because$ Age, Ed, Location $\leadsto$ Age, Ed $\quad$ Age $\quad$ No Controls 
Fig. 5a: Black-White Median Regression Log Differences for Annual, Weekly, and Hourly Earnings, 2000-2010

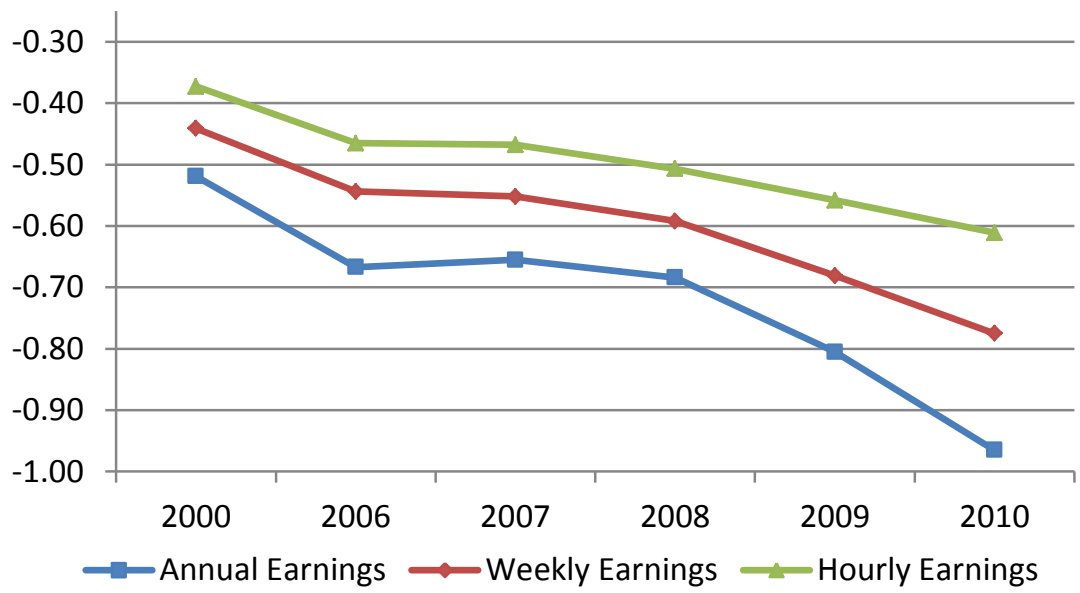

Fig. 5c: Black-White Median Regression Log Annual

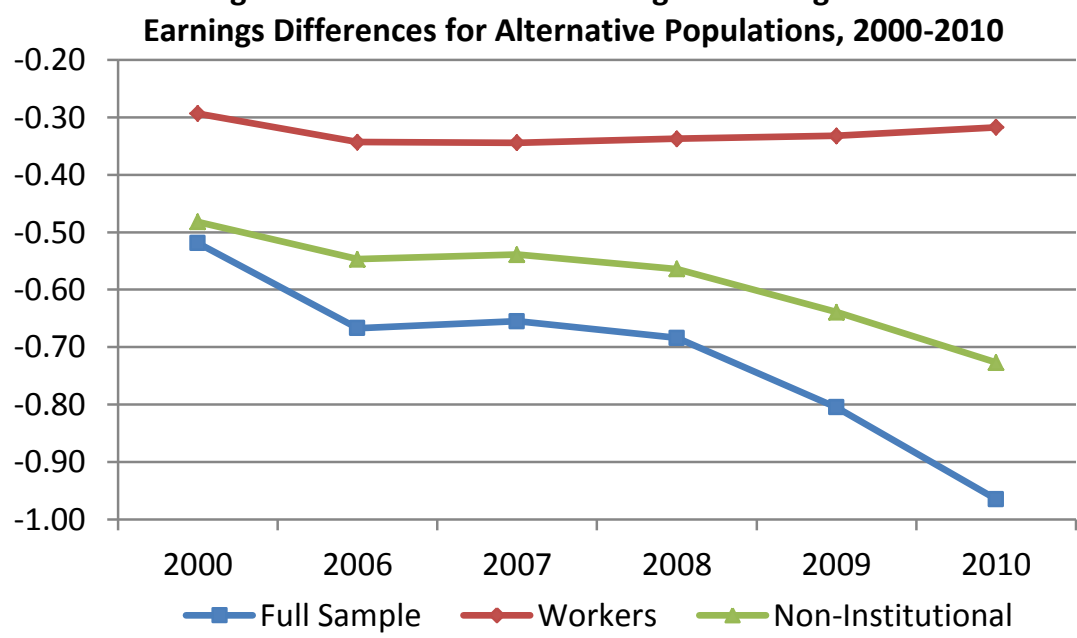

Fig. 5b: Hispanic-White Median Regression Log Differences

for Annual, Weekly, and Hourly Earnings, 2000-2010

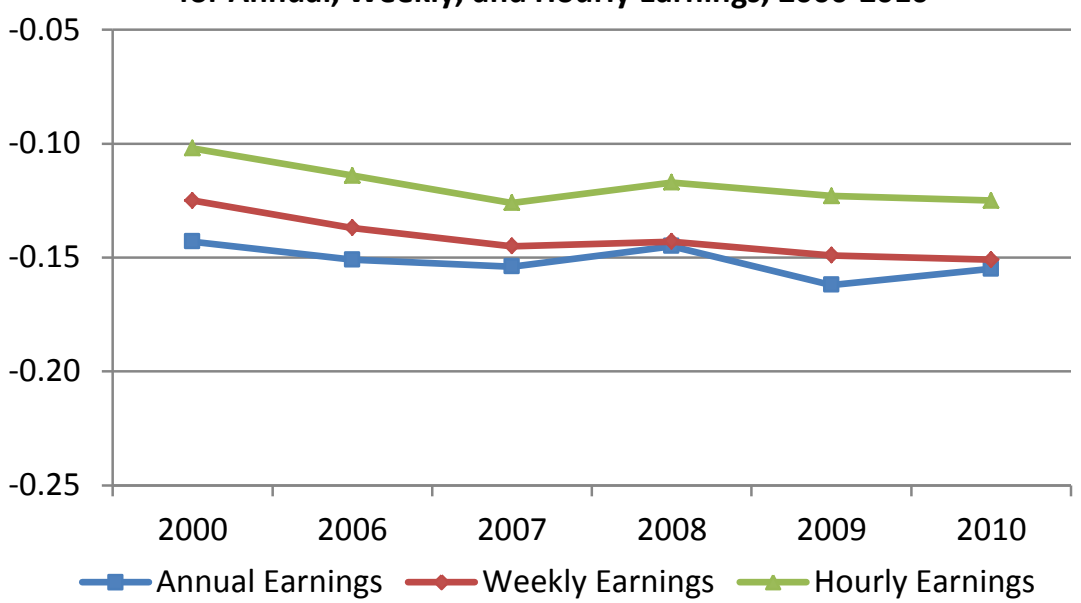

Fig. 5d: Hispanic-White Median Regression Log Annual Earnings Differences for Alternative Populations, 2000-2010

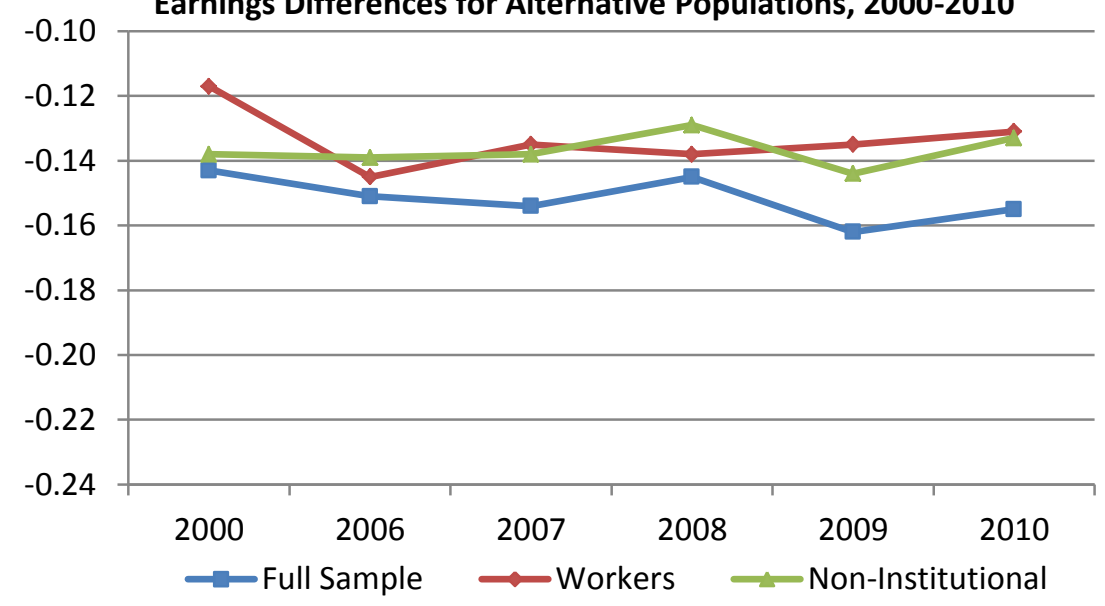


Table 1: Median Annual, Weekly, and Hourly Earnings, and Annual Hours, 2000

\begin{tabular}{lcccc}
\hline & Annual Earnings & Weekly Earnings & Hourly Earnings & Annual Hours \\
\hline Black & 17,000 & 533 & 12.50 & 1920 \\
Hispanic & 21,000 & 538 & 12.64 & 2080 \\
White & 33,000 & 731 & 16.50 & 2080 \\
& & & & \\
Log difference & & & & \\
Black-white & -0.663 & -0.316 & -0.277 & -0.080 \\
Hispanic-white & -0.452 & -0.305 & -0.266 & -0.000 \\
\hline
\end{tabular}

Table 2: Median Regression Log Annual Earnings Results, 1950-2010

\begin{tabular}{|c|c|c|c|c|c|c|c|c|c|c|c|}
\hline & 1950 & 1960 & 1970 & 1980 & 1990 & 2000 & 2006 & 2007 & 2008 & 2009 & 2010 \\
\hline \multicolumn{12}{|c|}{ A. No controls } \\
\hline Black & -0.713 & -0.747 & -0.582 & -0.628 & -0.654 & -0.663 & -0.903 & -0.891 & -0.916 & -1.153 & -1.601 \\
\hline Hispanic & -0.498 & -0.320 & -0.362 & -0.405 & -0.446 & -0.452 & -0.433 & -0.445 & -0.431 & -0.460 & -0.579 \\
\hline \multicolumn{12}{|c|}{ B. Control for age } \\
\hline Black & -0.673 & -0.683 & -0.526 & -0.572 & -0.563 & -0.624 & -0.807 & -0.780 & -0.821 & -1.029 & -1.344 \\
\hline Hispani & -0.350 & -0.249 & -0.268 & -0.270 & -0.285 & -0.281 & -0.273 & -0.258 & -0.260 & -0.310 & -0.310 \\
\hline \multicolumn{12}{|c|}{ C. Controls for age and education } \\
\hline Black & -0.389 & -0.472 & -0.366 & -0.425 & -0.422 & -0.470 & -0.608 & -0.596 & -0.620 & -0.734 & -0.900 \\
\hline Hispanic & -0.088 & -0.059 & -0.128 & -0.118 & -0.149 & -0.121 & -0.103 & -0.102 & -0.098 & -0.118 & -0.101 \\
\hline \multicolumn{12}{|c|}{ D. Controls for age, education, location } \\
\hline Black & -0.389 & -0.468 & -0.389 & -0.438 & -0.456 & -0.519 & -0.667 & -0.655 & -0.684 & -0.805 & -0.965 \\
\hline Hispanic & -0.144 & -0.124 & -0.128 & -0.122 & -0.151 & -0.143 & -0.151 & -0.154 & -0.145 & -0.162 & -0.155 \\
\hline
\end{tabular}

Notes: Coefficients are from median regression of log annual earnings on indicator variables for black and Hispanic. Panels B, C, and D also progressively add additional detailed dummy controls for age, education level, and geographic location. Each sample includes all non-student, native-born black, Hispanic, and white males ages 18-61 in the decennial Census or American Community Survey public use microdata samples with earnings not allocated (see text for details). Sample sizes for all groups and years are sufficiently large that all coefficients are statistically significant at the one percent level, so standard errors are not reported. 
Table 3: Median Regression Results, Alternative Specifications and Samples, 2000-2010

\begin{tabular}{|c|c|c|c|c|c|c|c|}
\hline & 2000 & 2006 & 2007 & 2008 & 2009 & 2010 & $\Delta 2000-2010$ \\
\hline \multicolumn{8}{|c|}{ A. Annual earnings - primary sample } \\
\hline Black & -0.519 & -0.667 & -0.655 & -0.684 & -0.805 & -0.965 & -0.446 \\
\hline Hispanic & -0.143 & -0.151 & -0.154 & -0.145 & -0.162 & -0.155 & -0.012 \\
\hline \multicolumn{8}{|c|}{ B. Weekly earnings - primary sample } \\
\hline Black & -0.441 & -0.544 & -0.552 & -0.592 & -0.681 & -0.775 & -0.334 \\
\hline Hispanic & -0.125 & -0.137 & -0.145 & -0.143 & -0.149 & -0.151 & -0.026 \\
\hline \multicolumn{8}{|c|}{ C. Hourly earnings - primary sample } \\
\hline Black & -0.373 & -0.465 & -0.468 & -0.507 & -0.558 & -0.611 & -0.238 \\
\hline Hispanic & -0.102 & -0.114 & -0.126 & -0.117 & -0.123 & -0.125 & -0.023 \\
\hline \multicolumn{8}{|c|}{ D. Annual hours - primary sample } \\
\hline Black & -0.085 & -0.134 & -0.134 & -0.116 & -0.224 & -0.436 & -0.351 \\
\hline Hispanic & -0.012 & 0.000 & 0.000 & 0.000 & 0.000 & -0.004 & 0.008 \\
\hline \multicolumn{8}{|c|}{ E. Annual earnings - worker-only sample } \\
\hline Black & -0.293 & -0.343 & -0.344 & -0.337 & -0.332 & -0.317 & -0.024 \\
\hline Hispanic & -0.117 & -0.145 & -0.135 & -0.138 & -0.135 & -0.131 & -0.014 \\
\hline \multicolumn{8}{|c|}{ F. Annual Earnings - Non-Institutionalized Sample } \\
\hline Black & -0.482 & -0.547 & -0.539 & -0.564 & -0.639 & -0.727 & -0.245 \\
\hline Hispanic & -0.138 & -0.139 & -0.138 & -0.129 & -0.144 & -0.133 & 0.005 \\
\hline \multicolumn{8}{|c|}{ G. Annual earnings - Primary sample plus foreign born } \\
\hline Black & -0.532 & -0.650 & -0.629 & -0.656 & -0.775 & -0.971 & -0.439 \\
\hline Hispanic & -0.186 & -0.176 & -0.177 & -0.165 & -0.160 & -0.115 & 0.071 \\
\hline \multicolumn{8}{|c|}{ H. Annual earnings - Primary sample plus imputed earners } \\
\hline Black & -0.518 & -0.575 & -0.565 & -0.607 & -0.668 & -0.757 & -0.239 \\
\hline Hispanic & -0.181 & -0.167 & -0.164 & -0.161 & -0.159 & -0.149 & 0.032 \\
\hline
\end{tabular}

Notes: Shown are log point earnings differentials. The primary sample includes all non-student, native-born white, black, and Hispanic men, ages 18-61, who report earnings (i.e., allocated earners are excluded where possible; see text for details). All regressions include detailed dummies for age, education, and location. 
Table 4: Non-Earnings Shares and the Treatment of Imputed Earners

\begin{tabular}{|c|c|c|c|c|c|c|}
\hline & 2000 & 2006 & 2007 & 2008 & 2009 & 2010 \\
\hline \multicolumn{7}{|c|}{ A. Share with No Earnings - Excluding Imputed Earners and Reweighting } \\
\hline Black & 0.289 & 0.316 & 0.320 & 0.330 & 0.369 & 0.419 \\
\hline Hispanic & 0.170 & 0.170 & 0.175 & 0.176 & 0.209 & 0.241 \\
\hline White & 0.103 & 0.117 & 0.118 & 0.123 & 0.138 & 0.166 \\
\hline \multicolumn{7}{|c|}{ B. Share with No Earnings - Excluding Imputed Earners No Reweighting } \\
\hline Black & 0.274 & 0.309 & 0.312 & 0.320 & 0.362 & 0.413 \\
\hline Hispanic & 0.161 & 0.166 & 0.171 & 0.171 & 0.205 & 0.236 \\
\hline White & 0.099 & 0.116 & 0.117 & 0.120 & 0.136 & 0.164 \\
\hline \multicolumn{7}{|c|}{ C. Share with No Earnings - Including Imputed Earners } \\
\hline Black & 0.249 & 0.251 & 0.253 & 0.267 & 0.301 & 0.341 \\
\hline Hispanic & 0.161 & 0.142 & 0.145 & 0.146 & 0.174 & 0.198 \\
\hline White & 0.092 & 0.103 & 0.104 & 0.109 & 0.123 & 0.144 \\
\hline \multicolumn{7}{|c|}{ D. Share with No Earnings - Imputed Earners Only } \\
\hline Black & 0.206 & 0.089 & 0.092 & 0.129 & 0.123 & 0.138 \\
\hline Hispanic & 0.162 & 0.052 & 0.053 & 0.061 & 0.062 & 0.069 \\
\hline White & 0.066 & 0.032 & 0.035 & 0.051 & 0.049 & 0.053 \\
\hline
\end{tabular}

Table 5: Log Annual Earnings Gaps at Various Percentiles - Full Controls, 2000-2010

\begin{tabular}{ccccccc}
\hline & \multicolumn{3}{c}{ White-Black Gap } & \multicolumn{3}{c}{ White-Hispanic Gap } \\
\hline Percentile & 2000 & 2010 & $\Delta 2000-2010$ & 2000 & 2010 & $\Delta 2000-2010$ \\
\hline 20 & -3.571 & -1.468 & 2.103 & -0.351 & -0.437 & -0.086 \\
30 & -1.221 & -4.489 & -3.268 & -0.188 & -0.284 & -0.096 \\
40 & -0.689 & -1.520 & -0.831 & -0.163 & -0.188 & -0.025 \\
50 & -0.519 & -0.965 & -0.446 & -0.143 & -0.155 & -0.012 \\
60 & -0.436 & -0.680 & -0.244 & -0.131 & -0.147 & -0.016 \\
70 & -0.387 & -0.550 & -0.163 & -0.131 & -0.139 & -0.008 \\
80 & -0.356 & -0.470 & -0.114 & -0.135 & -0.152 & -0.017 \\
90 & -0.344 & -0.424 & -0.080 & -0.151 & -0.166 & -0.015 \\
\hline
\end{tabular}

Notes: All regressions include detailed dummies for age, education, and location. 
Appendix Table A: The Share of Non-Earners and Annual Earnings Quantiles by Race/Ethnicity, 1950-2010

\begin{tabular}{|c|c|c|c|c|c|c|c|c|c|c|c|}
\hline & 1950 & 1960 & 1970 & 1980 & 1990 & 2000 & 2006 & 2007 & 2008 & 2009 & 2010 \\
\hline \multicolumn{12}{|c|}{ Share with No Earnings } \\
\hline Black & 0.123 & 0.124 & 0.150 & 0.211 & 0.224 & 0.289 & 0.316 & 0.320 & 0.330 & 0.369 & 0.419 \\
\hline Hispanic & 0.130 & 0.075 & 0.098 & 0.115 & 0.136 & 0.170 & 0.170 & 0.175 & 0.176 & 0.209 & 0.241 \\
\hline White & 0.081 & 0.058 & 0.062 & 0.071 & 0.074 & 0.103 & 0.117 & 0.118 & 0.123 & 0.138 & 0.166 \\
\hline \multicolumn{12}{|c|}{ 25th Percentile } \\
\hline Black & 3,150 & 4,294 & 5,674 & 2,306 & 1,344 & 0 & 0 & 0 & 0 & 0 & 0 \\
\hline Hispanic & 4,550 & 8,874 & 9,306 & 10,338 & 8,061 & 7,000 & 5,625 & 5,703 & 5,519 & 2,946 & 462 \\
\hline White & 8,750 & 15,744 & 16,796 & 18,530 & 17,735 & 17,000 & 14,272 & 14,666 & 14,191 & 11,628 & 7,856 \\
\hline \multicolumn{12}{|c|}{ 50th Percentile } \\
\hline Black & 8,750 & 12,881 & 18,385 & 18,370 & 17,466 & 17,000 & 12,593 & 13,037 & 12,614 & 9,302 & 5,546 \\
\hline Hispanic & 10,850 & 19,752 & 22,925 & 22,959 & 21,497 & 21,000 & 20,148 & 20,370 & 20,498 & 18,604 & 15,405 \\
\hline White & 17,850 & 27,194 & 32,911 & 34,433 & 33,589 & 33,000 & 31,062 & 31,777 & 31,535 & 29,457 & 27,498 \\
\hline \multicolumn{12}{|c|}{ 75th Percentile } \\
\hline Black & 14,350 & 22,042 & 31,096 & 33,859 & 33,589 & 32,000 & 29,383 & 29,332 & 29,406 & 27,131 & 26,188 \\
\hline Hispanic & 19,250 & 29,484 & 36,543 & 39,022 & 37,619 & 36,000 & 36,938 & 36,665 & 37,053 & 34,883 & 33,891 \\
\hline White & 25,550 & 36,927 & 45,622 & 50,496 & 51,055 & 52,000 & 50,370 & 52,961 & 51,244 & 50,386 & 48,525 \\
\hline \multicolumn{12}{|c|}{ 90th Percentile } \\
\hline Black & 19,950 & 28,912 & 41,083 & 45,907 & 48,368 & 50,000 & 46,173 & 48,887 & 47,302 & 46,510 & 45,444 \\
\hline Hispanic & 26,943 & 39,789 & 49,027 & 52,791 & 53,742 & 55,000 & 56,247 & 57,035 & 56,763 & 54,262 & 53,917 \\
\hline White & 35,350 & 51,240 & 65,823 & 68,854 & 73,895 & 80,000 & 83,951 & 81,479 & 79,625 & 77,517 & 77,024 \\
\hline
\end{tabular}

Notes: Annual Earnings are in 1999 dollars. Each sample includes all native-born Black, Hispanic, and White males ages 18-61 in the decennial Census or American Community Survey public use microdata samples not in school and with non-allocated earnings information. 
Appendix Table B: Share with No Annual Earnings by Age and Education Group, 2000 and 2010

\begin{tabular}{|c|c|c|c|c|c|c|c|c|c|c|c|c|c|c|c|}
\hline & \multicolumn{5}{|c|}{ Black } & \multicolumn{5}{|c|}{ Hispanic } & \multicolumn{5}{|c|}{ White } \\
\hline & $<\mathrm{HS}$ & $\begin{array}{c}\text { HS } \\
\text { Grads }\end{array}$ & $\begin{array}{l}\text { Some } \\
\text { Coll. }\end{array}$ & $\begin{array}{l}\text { Coll. } \\
\text { Grad. }\end{array}$ & Total & $<\mathrm{HS}$ & $\begin{array}{c}\text { HS } \\
\text { Grads }\end{array}$ & $\begin{array}{l}\text { Some } \\
\text { Coll. }\end{array}$ & $\begin{array}{l}\text { Coll. } \\
\text { Grad. }\end{array}$ & Total & $<\mathrm{HS}$ & $\begin{array}{c}\text { HS } \\
\text { Grads }\end{array}$ & $\begin{array}{l}\text { Some } \\
\text { Coll. }\end{array}$ & $\begin{array}{l}\text { Coll. } \\
\text { Grad. }\end{array}$ & Total \\
\hline \multicolumn{16}{|l|}{2000} \\
\hline Age 18-24 & 0.62 & 0.33 & 0.17 & 0.11 & 0.39 & 0.35 & 0.18 & 0.06 & 0.05 & 0.21 & 0.24 & 0.10 & 0.05 & 0.05 & 0.11 \\
\hline Age $25-29$ & 0.56 & 0.24 & 0.09 & 0.05 & 0.23 & 0.30 & 0.11 & 0.04 & 0.04 & 0.12 & 0.18 & 0.06 & 0.03 & 0.02 & 0.05 \\
\hline Age $30-34$ & 0.56 & 0.22 & 0.09 & 0.03 & 0.21 & 0.30 & 0.13 & 0.04 & 0.02 & 0.12 & 0.21 & 0.07 & 0.03 & 0.01 & 0.06 \\
\hline Age 35-39 & 0.54 & 0.22 & 0.10 & 0.06 & 0.22 & 0.33 & 0.14 & 0.04 & 0.02 & 0.13 & 0.25 & 0.08 & 0.04 & 0.02 & 0.07 \\
\hline Age $40-44$ & 0.52 & 0.25 & 0.14 & 0.06 & 0.25 & 0.34 & 0.16 & 0.07 & 0.04 & 0.15 & 0.28 & 0.09 & 0.06 & 0.02 & 0.08 \\
\hline Age $45-49$ & 0.55 & 0.30 & 0.17 & 0.07 & 0.29 & 0.36 & 0.17 & 0.12 & 0.04 & 0.18 & 0.35 & 0.12 & 0.07 & 0.03 & 0.10 \\
\hline Age $50-54$ & 0.56 & 0.34 & 0.21 & 0.11 & 0.33 & 0.38 & 0.23 & 0.13 & 0.07 & 0.22 & 0.38 & 0.17 & 0.11 & 0.05 & 0.13 \\
\hline Age 55-61 & 0.60 & 0.42 & 0.30 & 0.18 & 0.43 & 0.45 & 0.27 & 0.21 & 0.14 & 0.31 & 0.44 & 0.27 & 0.21 & 0.14 & 0.24 \\
\hline Total & 0.57 & 0.28 & 0.15 & 0.08 & 0.29 & 0.35 & 0.16 & 0.07 & 0.04 & 0.17 & 0.30 & 0.12 & 0.07 & 0.04 & 0.10 \\
\hline \multicolumn{16}{|l|}{2010} \\
\hline Age $18-24$ & 0.78 & 0.51 & 0.31 & 0.17 & 0.54 & 0.50 & 0.31 & 0.18 & 0.08 & 0.33 & 0.46 & 0.22 & 0.10 & 0.04 & 0.21 \\
\hline Age $25-29$ & 0.73 & 0.43 & 0.21 & 0.08 & 0.39 & 0.38 & 0.22 & 0.12 & 0.04 & 0.20 & 0.38 & 0.17 & 0.07 & 0.03 & 0.12 \\
\hline Age $30-34$ & 0.68 & 0.43 & 0.21 & 0.06 & 0.37 & 0.39 & 0.20 & 0.09 & 0.03 & 0.18 & 0.35 & 0.16 & 0.07 & 0.02 & 0.11 \\
\hline Age $35-39$ & 0.67 & 0.38 & 0.19 & 0.06 & 0.33 & 0.38 & 0.21 & 0.10 & 0.04 & 0.17 & 0.38 & 0.16 & 0.08 & 0.03 & 0.11 \\
\hline Age $40-44$ & 0.72 & 0.40 & 0.23 & 0.08 & 0.35 & 0.47 & 0.23 & 0.14 & 0.03 & 0.21 & 0.43 & 0.18 & 0.10 & 0.04 & 0.13 \\
\hline Age 45-49 & 0.70 & 0.42 & 0.25 & 0.09 & 0.38 & 0.42 & 0.26 & 0.15 & 0.06 & 0.23 & 0.44 & 0.19 & 0.12 & 0.05 & 0.15 \\
\hline Age $50-54$ & 0.69 & 0.46 & 0.33 & 0.16 & 0.43 & 0.48 & 0.28 & 0.19 & 0.07 & 0.26 & 0.52 & 0.22 & 0.16 & 0.08 & 0.18 \\
\hline Age 55-61 & 0.73 & 0.55 & 0.45 & 0.28 & 0.52 & 0.56 & 0.38 & 0.36 & 0.15 & 0.36 & 0.60 & 0.34 & 0.27 & 0.16 & 0.28 \\
\hline Total & 0.72 & 0.45 & 0.27 & 0.12 & 0.42 & 0.45 & 0.26 & 0.15 & 0.06 & 0.24 & 0.46 & 0.21 & 0.13 & 0.06 & 0.17 \\
\hline
\end{tabular}

